\title{
Drinking water disinfection by-products during pregnancy and child neuropsychological development in the INMA Spanish cohort study
}

Cristina M Villanueva ${ }^{1,2,3,4}$, Esther Gracia-Lavedan ${ }^{1,2,3}$, Jordi Julvez ${ }^{1,2,3,4}$, Loreto Santa-Marina ${ }^{3,5,7}$, Nerea Lertxundi ${ }^{6,7}$, Jesús Ibarluzea ${ }^{3,5,6,7}$, Sabrina Llop ${ }^{3,8}$, Ferran Ballester $^{3,8}$, Ana Fernández-Somoano, ${ }^{3,9}$, Adonina Tardón ${ }^{3,9}$, Martine Vrijheid ${ }^{1,2,3}$, Mònica Guxens ${ }^{1,2,3,10}$, Jordi Sunyer ${ }^{1,2,3,4}$

1) ISGlobal, Centre for Research in Environmental Epidemiology (CREAL), Barcelona, Spain

2) Universitat Pompeu Fabra (UPF), Barcelona, Spain

3) CIBER Epidemiología y Salud Pública (CIBERESP), Madrid, Spain

4) IMIM (Hospital del Mar Medical Research Institute), Barcelona, Spain

5) BIODONOSTIA Health Research Institute, San Sebastian, Basque Country, Spain

6) Faculty of Psychology, University of the Basque Country UPV/EHU, San Sebastian, Basque Country, Spain

7) Sub-Directorate for Public Health of Guipúzcoa, Department of Health, Government of the Basque Country, San Sebastian, Spain

8) Epidemiology and Environmental Health Joint Research Unit, FISABIO-Universitat Jaume I-Universitat de València, Valencia,Spain

9) Preventive Medicine and Public Health Area, Department of Medicine, University of Oviedo, Asturias, Spain

10) Department of Child and Adolescent Psychiatry/Psychology, Erasmus University Medical Centre-Sophia Children's Hospital, Rotterdam, The Netherlands

Corresponding author:

Cristina M Villanueva

ISGlobal

Parc de Recerca Biomèdica de Barcelona (PRBB)

Doctor Aiguader, 88

08003-Barcelona, Spain

Tel. (+34) 932147344

E-mail: cristina.villanueva@isglobal.org 


\section{ABSTRACT}

1 Background. Disinfection by-products (DBPs) constitute a complex mixture of

2 prevalent chemicals in drinking water and there is evidence of neurotoxicity for some

3 of them.

4 Objectives. We evaluated the association between estimates of DBP exposure

5 during pregnancy and child neuropsychological outcomes at 1 and 4-5 years of age.

6 Methods. We conducted a population-based mother-child cohort study in Spain with

7 recruitment at first trimester of gestation (INMA Project, 2003-2008).

8 Neuropsychological development was measured at 1 year of age using the Bayley

9 Scales of Infant Development and at 4-5 years with the McCarthy Scales of

10 Children's Abilities. Modeled tap water concentrations of trihalomethanes (THM) were

11 combined with personal ingestion, showering and bathing habits to estimate 12 exposure as ingestion uptake, all route (showering, bathing, ingestion) uptake 13 ( $\mu \mathrm{g} /$ day) and crude levels $(\mu \mathrm{g} / \mathrm{l})$ in the residence. Chloroform, brominated THMs 14 (bromodichloromethane, dibromochloromethane, bromoform) and total THMs 15 (chloroforom and bromianted THMs) were analysed separately. Nine haloacetic acids levels were available in one of the areas. Linear regression was used to estimate associations in 1855 subjects adjusting for covariables.

Results. The median concentration of total THMs, chloroform, brominated THMs, total haloacetic acids, dichloroacetic acid, and trichloroacetic acid were, respectively $30.3 \mu \mathrm{g} / \mathrm{L}, \quad 9.4 \mu \mathrm{g} / \mathrm{L}, 11.6 \mu \mathrm{g} / \mathrm{L}, 10.5 \mu \mathrm{g} / \mathrm{L}, 2.7 \mu \mathrm{g} / \mathrm{L}$, and $3.1 \mu \mathrm{g} / \mathrm{L}$. The associations between THM exposure and neuropsychological outcomes were null, except for total and brominated THM uptake though all routes and the general cognitive score at 4-5 years, with a decrease in -0.54 points $(95 \% \mathrm{Cl}-1.03,-0.05)$ and $-0.64(95 \% \mathrm{Cl}-1.16$, 0.12), respectively, for doubling total and brominated THM uptake. A positive 
1 association found between dichloroacetic acid and the mental score at 1 year did not

2 persist at $4-5$ years.

3 Conclusions. Minor associations observed between DBP exposure during gestation

4 and child neuropshychological development at 1 year disappeared at 4-5 years.

5 Although a suggestive association is identified for exposure to brominated THMs and

6 the cognitive score at 4-5 years, chance cannot be ruled out.

7

8

9 KEYWORDS: children, disinfection by-products, haloacetic acids, neurodevelopment, 10 trihalomethanes, water 
1. INTRODUCTION

2 Disinfection by-products (DBPs) are widespread chemicals in drinking water

3 produced as undesired side effects of disinfection process, which is necessary to

4 remove pathogens and prevent waterborne infections. Trihalomethanes (THMs) and

5 haloacetic acids (HAAs) are the two classes at highest concentrations when the

6 disinfectant used is chlorine-based (Richardson et al. 2007). Some DBPs, such as

7 THMs are volatile and skin permeable and human exposure occur through different

8 routes (ingestion, inhalation, skin contact) in activities involving water contact such as

9 showering, bathing, swimming in pools, and intake of water and water-based fluids (Villanueva et al. 2015). On the contrary, HAAs are not volatile or skin permeable and incorporation is mainly through the ingestion route. Given the ubiquity of DBPs, the multiple routes involved and the potential adverse outcomes, DBPs constitute an environmental exposure of concern.

Trihalomethanes are a class of DBPs including chloroform, bromodichloromethane, dibromochloromethane and bromoform. The sum of these four is known as total THMs (TTHMS) and is regulated in the US and EU, among other countries, with a maximum contaminant level $(\mathrm{MCL})$ of $80 \mu \mathrm{g} / \mathrm{l}$ and $100 \mu \mathrm{g} / \mathrm{l}$, respectively (Villanueva et al. 2014). Haloacetic acids are a family of DBPs including 9 chemicals: monochloro-, dichloro-, trichloro-, monobromo-, dibromo-, tribromo-, bromochloro, bromodichloro, 21 and dibromochloroacetic acids. The sum of monochloro-, dichloro-, trichloro-, monobromo-, and dibromoacetic acid is regulated in the US with a MCL of $60 \mu \mathrm{g} / \mathrm{l}$ (Villanueva et al. 2014). Other DBPs, up to more than 700, have been identified in drinking water, including haloacetonitriles, haloketones among others (Richardson et 
1 al. 2007). These occur at much lower concentrations, in the range of $\mathrm{ng} / \mathrm{l}$ and are not

2 regulated in drinking water (Villanueva et al., 2014).

3

4 Dichloroacetic acid is a HAA with extensive evidence of neurotoxicity in humans at 5 high doses. Dichloroacete salts were used as a drug to treat several metabolic, 6 cardiovascular and cerebrovascular disorders in the past (Stacpoole et al. 1998). 7 Peripheral neuropathy (extremity weakness, decreased nerve conduction velocity, 8 ataxia, tremors) produced by dichloroacetate has been reported in humans 9 (Kaufmann et al. 2006; Spruijt et al. 2001; Stacpoole et al. 1979). Mechanisms suggested by experimental studies in animals involve degeneration of spinal cord 11 nerve fibers, myelin changes and gliosis, observed in rat brain and in vitro studies 12 (Felitsyn et al. 2007; Moser et al. 1999). Other haloacetic acids have been shown to produce neurotoxicity in experimental studies, including trichloroacetic acid (neuroembryopathic effect in rats exposed during organogenesis) (Singh 2006), dibromoacetic acid (neuromuscular toxicity in rats) (Moser et al. 2004), and monocloroacetic acid (neuronal cell death through oxidative stress in vitro) (Chen et al. 2013; Lu et al. 2015).

Chloroform used as a solvent has been classified as neurotoxic in humans (Grandjean \& Landrigan, 2006) but there is no human evidence on neurotoxicity of chloroforom or other THMs in drinking water. Autistic like behaviors have been observed in male mice after gestational and postnatal exposure to chloroforom and bromoform in drinking water (Guariglia et al. 2011). However, no evidence of neurotoxicity or neurobehavioural effects on motor activity has been observed in other animal studies (Balster \& Borzelleca 1982; Moser et al. 2007). Experimental 
1 evidence in animals from other DBPs occurring at lower levels in drinking water also

2 show effects in murine studies. Chloroacetonitrile crosses the placenta and fetal

3 blood-brain barrier and induces oxidative stress and apoptotic neurodegeneration in

4 fetal brain in mice (Ahmed et al. 2005). Dichloroacetonitrile induces oxidative stress

5 and developmental apoptotic imbalance in mouse fetal brain (Esmat et al. 2012).

6 Detrimental behavioral effects in mice exposed to chloral during the prenatal and

7 early postnatal period but no association among adult animals have been shown

8 (Kallman et al. 1984).

9

The developing brain and nervous system during gestation is particularly vulnerable

11 to environmental insults, with potential long-term consequences (Grandjean \& 12 Landrigan 2014). Small molecules such as chloroform crosses the placenta and can 13 reach the fetus in humans (Dowty et al. 1976), but there is no evidence on the transplacental transmission for other DBPs. Given the widespread character of DBP exposure and the existing evidence suggesting potential neurotoxicity, the evaluation of neurodevelopmental impacts of DBP exposure in utero is warranted. We specifically aim to evaluate the association between markers of DBP exposure during pregnancy and neuropsychological outcomes at 1 and 4-5 years of age in a population-based mother-child cohort study in Spain.

\section{METHODS}

\subsection{Study design and population}

23 A mother-child cohort study was set up in 4 Spanish areas (Asturias, Gipuzkoa, 24 Sabadell and Valencia) following a common protocol to constitute the INMA 25 INfancia y Medio Ambiente [Environment and Childhood] Project. For a detailed 
1 description of study areas see Supplemental Material. Study subjects were recruited

2 at the first trimester of gestation and followed until delivery. Eligibility criteria for

3 enrollment were maternal age 16 years or older, singleton pregnancy, planning to

4 deliver at the study hospitals, being able to communicate in either of the official

5 languages, and not having followed an assisted reproduction program (Guxens et al.

6 2012). The study sample was representative of the target population in terms of pre-

7 natal care attendance in the public health system (used by more than $80 \%$ of the 8 pregnant women). From $45 \%$ to $98 \%$ of the eligible pregnant women agreed to

9 participate and enrollment periods ranged from November 2003 in Valencia to February 2008 in Gipuzkoa (Guxens et al. 2012). Recruited subjects at the first 11 trimester of gestation were 494 in Asturias, 638 in Gipuzkoa, 657 in Sabadell and 12827 in Valencia. Follow-up occurred at the third trimester of gestation, delivery, 1 year and 4-5 years of age. From the initial sample at recruitment, 475 children (96\%) in Asturias, 599 (94\%) in Gipuzkoa, 583 (89\%) in Sabadell and 708 (86\%) in Valencia were included at the 1 year follow up and mothers confirmed informed consent to participate for their children. The follow up at 4-5 years included 2028 children (453 in Asturias, 505 in Gipuzkoa, 514 in Sabadell and 556 in Valencia). The study protocol was approved by the Institutional Ethical Committees of the participating centers, and all included mothers gave written and voluntary consent in each phase of the study prior participation. See Figure S2 for more details on included and excluded subjects.

\subsection{THM and HAA levels}

Chlorine was the main disinfectant used for drinking water in all the study areas. Sampling locations were defined a priori to cover geographically the study areas (see 
1 Supplemental Material Figure S1). Water samples were collected from the tap with

2 no filtration or other treatments that could affect THM or HAA concentration. Sample

3 collection in the different study areas was conducted by local study personnel, who

4 was specifically trained to follow a standardized procedure (see Supplemental

5 Material for details on Experimental THM and HAA analysis in tap water). The

6 sampling strategy did not consider individual pregnancy periods but covered the

7 period between the minimum and maximum conception dates of study subjects.

8 Trihalomethanes. Concentration of THMs was ascertained based on sampling 9 campaigns and regulatory data from local authorities and water companies. Measurements were conducted at different time points: 2004-2008 (Asturias), 20062008 (Gipuzkoa), 2004-2006 (Sabadell), and 2004-2005 (Valencia). THMs were

12 determined in 183 samples in Asturias (18 from our own sampling and 165 from regulatory measurements), 421 in Gipuzkoa (own sampling), 198 in Sabadell (148 own sampling, 50 regulatory), and 162 in Valencia (own sampling).

Haloacetic acids. Measurements of HAAs were available in one of the areas (Gipuzkoa), including 9 components: monochloro-, dichloro-, trichloro-, monobromo-, dibromo-, tribromo-, bromochloro, bromodichloro, and dibromochloroacetic acids. Only total, dichloro and trichloroacetic acid were further used to evaluate exposure since other HAAs occurred at low concentrations (Santa-Marina et al. 2010). A total of 264 measurements were conducted in 26 sampling points from 2007 to 2011.

\subsection{THM and HAA modeling}

Comparison of mean THM concentrations based on regulatory surveys and our own measurements did not show significant differences ( $p$-value from $t$-test $>0.10$ ), and data from both sources were used. Separate models for each area were conducted 
1 to predict total THM, chloroform, bromodichloromethane, dibromochloromethane, 2 bromoform, total haloacetic acids, dichloroacetic acid and trichloroacetic acid to assign a concentration to the distribution system of the municipality where women resided. For the modeling procedure, see Supplemental Material. Final models predicted average monthly levels from conception until delivery in each participant's residential water supply. Estimation of levels was not possible for all pregnancies followed to delivery because of missing concentration data in some municipalities, missing or incomplete address, or missing gestational age.

\subsection{Exposure indices}

Uptake factors (blood concentration) were used to convert exposure from different situations (ingestion, showering, bathing) to common units, to allow adding them and estimate total exposure at the residence. Uptake factors are available in the literature for THM only, and not for HAAs, thus precluding the study of HAA uptakes in the association of neuropsychological outcomes. The modeled residential THM level was multiplied by daily personal water use and uptake factors (see Supplemental Material Table S1), to derive an estimate of daily THM concentration in the bloodstream (Whitaker et al. 2003). Chloroform and brominated THM were analyzed separately because toxic properties differ among species, particularly brominated versus chlorinated species. A 90\% reduction in ingestion was applied if a home filter was used (Egorov et al. 2003; Weinberg et al. 2006). Water consumption outside the home was mainly bottled in all areas (90\% overall, range 79 to $96 \%$ ) and was not considered. We averaged the 12- and 32-week tap water intakes to compute the ingested THM. Average THM uptake in the first, second, and third trimester and the whole pregnancy were calculated. Bathing and showering uptakes were added, and 
1 total household uptake was calculated by adding ingestion, showering, and bathing.

2 More details on the exposure assessment is available in Villanueva et al. 2011.

3

4

\subsection{Outcomes}

Child neuropsychological development was measured at $\sim 14$ months of age (median 14, range:13-15) using the Bayley Scales of Infant Development (BSID) (Bayley 1993) by twelve experienced and trained psychologists in the presence of the mother at the primary care center. The BSID consists of two scales, the mental and the psychomotor scales. The mental scale consisted of 163 items that assessed ageappropriate cognitive development in areas such as performance ability, memory, and first verbal learning. The psychomotor scale consisted of 81 items assessing fine and gross psychomotor development. All assessments were carried out according to a strict field work protocol, and included inter-observer reliability tests estimated by intra-class correlation tests $(0.90$ for the mental scale and 0.91 for the psychomotor scale). Furthermore, Cronbach's Alpha Coefficient was used to determine the internal consistency per each of the scales. Scale Alpha Coefficients were around 0.70 (good to moderate). Raw scores were standardized for each child's age in days at the time of test administration using a parametric method for the estimation of age-specific reference intervals (Royston \& Wright 1998). The parameters of the distribution are modeled as a fractional polynomial function of age and estimated by maximum likelihood. Standardized residuals were centered to a mean of 100 with a standard deviation (SD) of 15 points. Participants for which neuropsychological tests were of poor quality due to neurodevelopmental disabilities (Down syndrome and autistic traits) or less-than-optimal cooperation of the child (due to tiredness, bad mood, or 
1 illness) were flagged by the psychologists during evaluation and excluded from our 2 analysis $(\mathrm{N}=150)$, see Figure $\mathrm{S} 2$.

3

The same children were interviewed/evaluated at 4-5 years of age (median: 4.5, range $4.4-5.6$ ) by six trained psychologists using a standardized Spanish version of the McCarthy Scales of Children's Abilities (MSCA) (McCarthy 1996). The MSCA comprises 18 subtests that provide information on 5 scales (verbal, perceptual performance, memory, quantitative, and motor functions) and one general scale which is the sum of verbal, perceptual and quantitative scales, since memory scale overlaps with the other subscales' subtests. The verbal scale refers to cognitive tasks related to the processing of verbal information; the perceptual performance scale refers to cognitive tasks related to perceptual information processing, including manual performance; the memory scale considers short-term retention of information (verbal, visual, or numerical); the quantitative scale refers to numerical abilities; and the motor scale refers to fine (e.g., drawing) and gross (e.g., balance or accuracy) functions. In order to reduce multiple comparison problems, the present analysis selected the motor scale and general cognitive scale in which both of them contain all MSCA subtests. Raw scores were centered on a mean of 100 with an SD of 15 . This was to obtain indexes in accordance with a local normative sample and to avoid the use of US norms provided in the manual. Testing was conducted according to a strict protocol, including neuropsychologist training, and for a small number of children, multiple neuropsychologist evaluations were performed with results reached by consensus. Alpha Coefficient for general cognitive scale was of 0.90 (excellent), MSCA motor subscale was of 0.64 each (good to moderate). 
1 The standardization differs between the two scales, BSID and MSCA. BSID raw

2 scores were regressed (fractional polynomials) on age and residuals of the

3 regression become the outcome of interest due to age disparity between child cohort regions at this developmental time, and due to their none-linear relation pattern observed. MSCA age cohort differences were less important and a there was strong linear age-outcome pattern that allowed us to center scores on a mean of 100 with and SD of 15 and further include child age in the regression models, which is a simpler and preferred outcome modeling.

\subsection{Covariables}

Parental and prenatal variables potentially influencing the evaluated outcomes were considered. Maternal age, height, pre-pregnancy weight, education, marital status, parity, country of birth (European, non-European) and paternal weight were collected at enrolment (first trimester of gestation). Smoking and alcohol consumption during pregnancy was recorded at third trimester of pregnancy. Date of the last menstrual period was used as conception date. Maternal weight gain during pregnancy was computed as the rate of weight gain during the second and third trimester in $\mathrm{kg}$ per week (Rasmussen \& Yaktine 2009), adjusted for gestational age at the last available weight measure to correct possible heteroscedasticity and nonlinearity of the rate (Dietz et al. 2006). Maternal social class was coded from the longest held job during the pregnancy, using the 4-digit Spanish classification (CNO 1994), which is closely related to the (ISCO 88). When the mother did not work during pregnancy $(19.6 \%$ of study subjects), the longest held job in the previous 10 years was used to define social class. Among women who did not have a paid job in the previous 10 years (1.5\%), the occupation of the father was used. A proxy of maternal verbal intelligence 
1 quotient (IQ) was measured through the Similarities subtest of the Wechsler Adult

2 Intelligence-Third Edition (WAIS-III) at the 4-5 year follow up. Use of bleach during

3 pregnancy was ascertained at week 32 , and was explored in the models as cleaning

4 has been identified as a source of THM exposure (Charisiadis et al. 2014).

\subsection{Statistical analyses}

A total of 1855 subjects were included in the BSID models at 1 year and 1453 in the MSCA models at 4-5 years (see Figure S2). Chloroform, brominated THMs, and total THM exposures were log transformed to normalize the distribution. We evaluated the association between the outcomes and log10 THM uptake and THM levels by linear regression adjusting for area, age at examination, sex, psychologist, quality of the test, parity and maternal age, social class, born in Europe, alcohol and smoking during pregnancy, height, pre-pregnancy body mass index, and weight gain during pregnancy. These were statistically significant covariates ( $p$-value $<0.05$ ) or variables that modified $\geq 10 \%$ the $\beta$-coefficient either for BSID or MSCA outcomes. Missing values in some covariables yielded a slightly lower number of subjects included in the multivariate models. The effect of additionally adjusting for maternal IQ was estimated among the subset with available maternal IQ score $(\mathrm{N}=1351)$. To facilitate the interpretation of the associations as a change in the outcome for doubling exposure, coefficients from the regression models were multiplied by the logarithm of 2. Main analyses were conducted for average exposure in pregnancy. Alternative analyses were stratified by sex, given that previous evidence suggested an effect modification by sex (Guariglia et al. 2011), area, exposure by trimester of pregnancy, and social class. Sensitivity analyses were conducted by excluding children born preterm (4\%) and those changing address during pregnancy (4\%). Generalized 
1 additive models (GAMs) were used to evaluate the shape of the dose-response

2 curves. pregnancy occurred among 31\% and 9\%, respectively.

The water use habits in the residence leading to DBP exposure are shown in Table

2. While showering and bathing habits were similar among areas, the type of drinking water consumed at home varied widely. Overall, bottled water consumption was the main source of drinking water at home, with an average of $62 \%$ ranging from $24 \%$ (Gipuzkoa) to $87 \%$ (Sabadell). In contrast, type of water consumed outside home was mostly bottled in all areas.

As shown in Figure 1, median level of total THMs in the residential tap water during pregnancy was $30.3 \mu \mathrm{g} / \mathrm{L}$ (percentile 25-percentile 75: $11.6-96.3 \mu \mathrm{g} / \mathrm{L}$ ) in all areas combined. By area, the median ranged from $5.0 \mu \mathrm{g} / \mathrm{L}$ (Valencia) to $117.1 \mu \mathrm{g} / \mathrm{L}$ (Sabadell). Median chloroform level was $9.4 \mu \mathrm{g} / \mathrm{L}$ (p25-p75: 3.5-21.4 $\mu \mathrm{g} / \mathrm{L}$ ) in all areas combined. By area, the median value ranged from $0.3 \mu \mathrm{g} / \mathrm{L}$ (Valencia) to 29.4 $\mu \mathrm{g} / \mathrm{L}$ (Asturias). Median brominated THM level was $11.6 \mu \mathrm{g} / \mathrm{L}$ (p25-p75: 7.4-86.9 $\mu \mathrm{g} / \mathrm{L}$ ) in all areas combined. By area, median ranged from $4.5 \mu \mathrm{g} / \mathrm{L}$ (Valencia) to 
$1 \quad 102.2 \mu \mathrm{g} / \mathrm{L}$ (Sabadell). Median total THM ingestion uptake was $0.001 \mu \mathrm{g} / \mathrm{day}$ ( $\mathrm{p} 25$ -

2 p75: $0.0004-0.04 \mu \mathrm{g} /$ day) in all areas combined. By area, median ranged from

$30.000017 \mu \mathrm{g} / \mathrm{day}$ (Valencia) to $0.036 \mu \mathrm{g} /$ day (Gipuzkoa). Median all route THM

4 uptake was $0.40 \mu \mathrm{g} /$ day (p25-p75: 0.14-1.25 $\mu \mathrm{g} /$ day) in all areas combined. By area,

5 median ranged from $0.11 \mu \mathrm{g} /$ day (Valencia) to $1.57 \mu \mathrm{g} /$ day (Sabadell). HAAs levels

6 were available in Gipuzkoa, with a median level of $2.7 \mu \mathrm{g} / \mathrm{L}$ (p25-p75: 1.8-4.0 $\mu \mathrm{g} / \mathrm{L}$ )

7 for dichloroacetic acid, $3.1 \mu \mathrm{g} / \mathrm{L}$ (p25-p75: 2.4-4.8 $\mu \mathrm{g} / \mathrm{L}$ ) for trichloroacetic acid, and $8 \quad 10.5 \mu \mathrm{g} / \mathrm{L}(\mathrm{p} 25-\mathrm{p} 75:$ 8.0-13.7 $\mu \mathrm{g} / \mathrm{L})$ for total haloacetic acids. Levels of HAAs and 9 THMs were correlated (see table S2), with highest correlations between 10 trichloroacetic acid (TCAA) and chloroform (Spearman rank correlation coefficient, $11 \mathrm{r}=0.85)$.

The outcome variables are continuous scores and higher values mean better performance in the neuropsychological tests. The distribution of the outcome variables is shown in Figure 2. The median raw mental/cognitive score was 114 (percentile 25-percentile 75: 109-119) points at 1 year and 135 (p25-p75: 117-162) points at 4-5 years in all areas combined. The median raw motor score was 51 (p25p75: 48-53) points at 1 year and 41 (p25-p75: 36-49) points at $4-5$ years in all areas combined. The variables used in the multivariate models were the centered to an average of 100 with standard deviation of 15.

The associations between exposure to total THM, chloroform and brominated THMs during pregnancy and neuropsychological outcomes at 1 year and 4-5 years are shown in Table 3 (total THMs) and Table 4 (chloroform, brominated THMs). The associations were generally null. However, residential uptake through all routes to 
1 total THMs (Table 3) and brominated THMs (Table 4) was associated with a slightly

2 reduced cognitive score at 4-5 years, with a decrease of -0.54 (95\% confidence

3 interval, $\mathrm{Cl},-1.03$ to -0.05$)$ and $-0.64(-1.16$ to -0.12$)$ points, respectively for doubling

4 total THM and Br-THMs uptake. These associations were similar, although not

5 statistically significant in the analyses separately for boys and girls, and by trimesters

6 of pregnancy (see Table S3). The GAM of the cognitive score at 4-5 years showed a

7 slightly decreasing curve with the continuous all route brominated THM uptake,

8 confirming a linear association (Figure 3). A positive association was found for the

9 mental score at 1 year among girls (Table 3), driven by brominated THMs (Table 4).

The GAMs showed flat curves (see Figure S3) and linear trends except for THM

11 levels and the mental score at 1 year, where the curve showed non-linear

12 associations ( $p$-value for gain compared to the linear model 0.03 ).

Adjusting for maternal IQ led to similar associations, with wider confidence intervals compared to results in Table 3 , with and effect of $-0.47(-0.96$ to 0.03$)$ for the cognitive score at 4-5 years associated with doubling all route THM uptake. Excluding preterm births and those that changed address during pregnancy led to similar associations compared to the main models in Table 3. The effect $(95 \% \mathrm{Cl})$ for the cognitive score at 4-5 years associated with doubling all route THM uptake was $0.61(-1.11$ to -0.11$)$ after excluding preterm births and $-0.62(-1.12$ to -0.12$)$ after excluding those changing address, and the number of observations of the models were, respectively 1373 and 1384 .

Analyses stratified by area showed mostly non- statistically significant associations around the null (see Table S4), similarly to the main combined analyses. A negative 
1 statistically significant association between all route THM uptake and the mental

2 score at 1 year was observed in Asturias (effect=-1.75, -3.47 to -0.04 ), where the

3 examination was done mostly after 1.5 years of age. A statistically significant positive

4 association is observed in Sabadell for ingestion THM uptake and the cognitive score

5 at 4-5 years (Table S4). An effect modification by social class is observed in the

6 association between the ingestion THM uptake and the motor score at 1 year (Table

7 S5).

8

9 The associations between levels of haloacetic acids during pregnancy and neuropsychological outcomes are shown in Table 5. A statistically significant positive association driven by girls is observed between dichloroacetic acid and the mental

12 score at 1 year, with an increase of 1.78 points (0.12 to 3.45$)$ for doubling dichloroacetic acid levels, that does not persist at $4-5$ years (effect $=0.91,-0.81$ to 2.62).

\section{DISCUSSION}

To our knowledge this is the first epidemiological study evaluating the association between markers of DBP exposure during pregnancy and neuropsychological outcomes in children. Average residential levels of total THMs, chloroform, brominated THMs, total haloacetic acids, dichloroacetic acid, and trichloroacetic acid

21 in the study areas were, respectively $50.5,12.7,34.5,11.3,3.0$, and 3.6 $\mu \mathrm{g} / \mathrm{L}$. A high proportion of women consumed bottled water during pregnancy and showeringbathing was the most important contributor to residential THM uptake. The associations for THM exposure were generally null, except from a small negative association between all route total $\mathrm{THM}$ and $\mathrm{Br}$-THM uptake and the general 
1 cognitive score at 4-5 years. There was an effect modification by sex for some

2 associations, and a positive association was found among girls for the mental score

3 at 1 year that did not persist at 4-5 years. Results were consistent among areas.

4

An overall interpretation of the associations evaluated for THM exposure indicates mostly lack of association between child neurodevelopment and exposure during pregnancy. A small but statistically significant association is suggested between total and brominated THMs and the cognitive score at 4-5 years, similar between boys and girls and for trimesters of exposure. A similar result is observed in the area with highest levels of brominated THMs (Sabadell), although the association is not statistically significant probably due to limited sample size. However, previous evidence is limited to sustain this association. Behavioral toxicity of brominated THM has been tested among adult mice, showing effects on operant behavior with development of tolerance (Balster \& Borzelleca 1982), and no neuropathological effects have been observed in a second study evaluating bromodichloromethane in rats (Moser et al. 2007). Other brominated DBPs evaluated in rats include dibromoacetonitrile and dibromoacetic acid, showing no effects for dibromoacetonitrile (Moser et al. 2007), while dibromoacetic acid produced concentration-related neuromuscular toxicity and degeneration of spinal cord nerve fibers (Moser et al. 2004). However, none of these studies evaluated prenatal exposure. In contrast, chloroform has been classified as neurotoxic solvent in humans (Grandjean \& Landrigan 2006), while we do not find any evidence of association in our study at the observed exposure levels. Our study is not comparable with the only, to our knowledge, evaluation of infant neuropsychological development in relation to water DBP exposure in humans, since they measured 
1 motor development at 6 months (Lin et al. 2011). In consequence, although

2 consistent and suggestive, the association we observe should be cautiously

3 interpreted and chance cannot be ruled out given the large number of tests

4 performed and the small magnitude of the association. We cannot discard, however,

5 that adverse effects of prenatal DBP exposure might appear later in childhood. The

6 prospective nature of the INMA Project, with neuropsychological developmental

Although dichloroacetic acid was the DBP with a higher prior related to neuropsychological development, the study had limited power and narrow exposure variability to test the effect of haloacetid acids, since data was only available in one of the areas. An unexpected positive association is observed between dichloroacetic acid levels and the mental score at 1 year driven by girls, that disappears at 4-5 years. In contrast, a negative (although not statistically significant) association was observed for trichloroacetic acid levels and the motor score at 1 year, that did not persist at 4-5 years either. The adverse effects previously observed for dichloroacetic acid have been reported at doses of 5-150 mg/day (Stacpoole et al. 1998), whereas average (maximum) ingested dose in the study area was $3.4 \mu \mathrm{g} / \mathrm{day}(13.8 \mu \mathrm{g} / \mathrm{day})$. In consequence, our results show that haloacetic acids at the levels observed here do not involve adverse effects on child neuropsychological development.

Our analysis was limited to prenatal exposure since data on postnatal exposure was not available for all cohorts. We cannot rule out an effect of postnatal exposure, and this deserves to be evaluated in future studies. Although we were careful to minimize 
1 measurement error, exposure misclassification is a concern and we cannot rule out

2 that it could partly explain the null associations. The use of THMs and HAAs as

3 surrogates of other DBPs has limitations. Other DBPs occurring at lower levels may

4 have an effect on the neuropsychological development (Ahmed et al. 2005; Esmat et

5 al. 2012), and these are poorly correlated with THMs and HAAs (Villanueva et al.

6 2012). The different distribution of levels between areas is a concern in the analysis

7 combining all the areas, for the possible ecological comparisons. However, despite

8 the differences, there was an overlap in the distributions allowing the all-area

9 combined analyses. The area-stratified analyses showed some discordances that

10 might suggest residual confounding. However, most of the associations were similar

11 to the all-area combined analyses, providing reliability to these results. The study

12 population had a higher educational level compared to the general population. To

13 address this, all multivariate models were adjusted for social class, and we further

14 tested the potential effect modification by social class. There was no evidence of

15 effect modification in most of the tests, except for the association between the motor

16 score at 4-5 years and ingestion THM uptake, suggesting an implausible positive

17 effect of the exposure among the wealthiest.

The main strengths of this study include its population-based prospective design, large sample size, a large number of covariables available and a common protocol

21 for exposure and outcome assessment across cohorts. Potential confounding was 22 addressed in multivariable analyses adjusted for a wide range of socioeconomic and 23 life-style factors. Residual confounding for other variables associated both with the exposure and the outcome is possible but unlikely. Finally, we include a population 
1 with a wide range of exposure, which allows the generalization of our results to other 2 settings.

3

\section{5. CONCLUSIONS}

5 Overall, results does not show a consistent association between exposure to drinking 6 water disinfection by-products during gestation and child neuropsychological 7 development at 1 and 4-5 years. Associations observed at 1 year did not persist at 485 y ears. Although a suggestive association is identified for exposure to brominated 9 THMs and the cognitive score at 4-5 years, chance cannot be ruled out. 
FUNDING: This study was funded by Grants from UE (FP7-ENV-2011 cod 282957 and HEALTH.2010.2.4.5-1), and from Spain: Instituto de Salud Carlos III (Red INMA G03/176, CB06/02/0041, FIS-FEDER 03/1615, 04/1509, 04/1112, 04/1931, PI041436, FIS-PI042018, 05/1079, 05/1052, 06/1213, FIS-PI06/0867, 07/0314, 081151, 09/02647, 09/02311, 09/00090, 11/0178, 11/02591, 11/02038, 13/1944, 13/2032, 13/02429, 13/02187, 14/0891, 14/1687, and Miguel Servet-FEDER MS15/0025, MS13/00054, CP0610034), CIBERESP, the Conselleria de Sanitat de la Generalitat Valenciana, Generalitat de Catalunya (CIRIT 1999SGR 00241), Fundació La Marató de TV3 (090430), Obra Social Cajastur/Fundación Liberbank, Universidad de Oviedo, Department of Health of the Basque Government (2005111093, 2009111069, 2013111089 and 2015111065), and the Provincial Government of Gipuzkoa (DFG06/002, DFG08/001 and DFG15/221). Annual agreements with the city council of the study area in Gipuzkoa (Zumarraga, Urretxu, Legazpi, Azkoitia y Azpeitia y Beasain). ISGlobal is a member of the CERCA Programme, Generalitat de Catalunya. 


\section{REFERENCES}

Ahmed, A. E., Campbell, G. A., \& Jacob, S. (2005). Neurological impairment in fetal mouse brain by drinking water disinfectant byproducts. Neurotoxicology, 26(4), 633-640.

Balster, R. L., \& Borzelleca, J. F. (1982). Behavioral toxicity of trihalomethane contaminants of drinking water in mice. Environ Health Perspect, 46, 127-136.

Bayley, N. (1993). Bayley Scales of Infant Development. San Antonio, TX: The Psychological Corporation;

Charisiadis, S. S. Andra, K. C. Makris, M. Christodoulou, C. A. Christophi, S. Kargaki, and E. G. Stephanou (2014). Household Cleaning Activities as Noningestion Exposure Determinants of Urinary Trihalomethanes. Environ Sci Technol, 48 (1), 770-780.

Chen, C. H., Chen, S. J., Su, C. C., Yen, C. C., Tseng, T. J., Jinn, T. R., ... Huang, C. F. (2013). Chloroacetic acid induced neuronal cells death through oxidative stressmediated p38-MAPK activation pathway regulated mitochondria-dependent apoptotic signals. Toxicology, 303, 72-82.

CNO. (1994). Clasificacion Nacional de Ocupaciones. www.ine.es.

Dietz, P. M., Callaghan, W. M., Cogswell, M. E., Morrow, B., Ferre, C., \& Schieve, L. A. (2006). Combined effects of prepregnancy body mass index and weight gain during pregnancy on the risk of preterm delivery. Epidemiology, 17(2), 170-177.

Dowty, B. J., Laseter, J. L., \& Storer, J. (1976). The transplacental migration and accumulation in blood of volatile organic constituents. Pediatr Res, 10(7), 696-701.

Egorov, A. I., Tereschenko, A. A., Altshul, L. M., Vartiainen, T., Samsonov, D., LaBrecque, B., ... Ford, T. E. (2003). Exposures to drinking water chlorination by-products in a Russian city. Int J Hyg Environ Health, 206(6), 539-551. 
Felitsyn, N., Stacpoole, P. W., \& Notterpek, L. (2007). Dichloroacetate causes reversible demyelination in vitro: potential mechanism for its neuropathic effect. $J$ Neurochem, 100(2), 429-436.

Grandjean, P., \& Landrigan, P. J. (2006). Developmental neurotoxicity of industrial chemicals. The Lancet, 368(9553), 2167-2178.

Grandjean, P., \& Landrigan, P. J. (2014). Neurobehavioural effects of developmental toxicity. Lancet Neurol, 13(3), 330-338.

Guariglia, S. R., Jenkins Jr., E. C., Chadman, K. K., \& Wen, G. Y. (2011). Chlorination byproducts induce gender specific autistic-like behaviors in CD-1 mice. Neurotoxicology, 32(5), 545-553.

Guxens, M., Ballester, F., Espada, M., Fernandez, M. F., Grimalt, J. O., Ibarluzea, J., ... Sunyer, J. (2012). Cohort Profile: The INMA--INfancia y Medio Ambiente--(Environment and Childhood) Project. Int J Epidemiol, 41(4), 930-940.

Kallman, M. J., Kaempf, G. L., \& Balster, R. L. (1984). Behavioral toxicity of chloral in mice: an approach to evaluation. Neurobehav Toxicol Teratol, 6(2), 137-146.

Kaufmann, P., Engelstad, K., Wei, Y., Jhung, S., Sano, M. C., Shungu, D. C., ... De Vivo, D. C. (2006). Dichloroacetate causes toxic neuropathy in MELAS: a randomized, controlled clinical trial. Neurology, 66(3), 324-330.

Lin, Y. J., Wang, G. S., \& Chen.P.C. (2011). The relationship between water disinfection byproducts and early childhood neurobehavioral development. In: Abstracts of the 2011 Conference of the International Society of Environmental Epidemiology (ISEE). Abstract 398. Research Triangle Park, NC:Envir. 
1 Lu, T. H., Su, C. C., Tang, F. C., Chen, C. H., Yen, C. C., Fang, K. M., ... Chen, Y. W. (2015). Chloroacetic acid triggers apoptosis in neuronal cells via a reactive oxygen species-induced endoplasmic reticulum stress signaling pathway. Chem Biol Interact., 225, 1-12.

McCarthy, D. (1996). Manual for the McCarthy Scales of Children's Abilities. New York, NY; 1972. Psychological Corp. Spanish Adaptation, Madrid, Spain: TEA Ediciones, S.A.; 1996. .

Moser, V. C., Phillips, P. M., Levine, A. B., McDaniel, K. L., Sills, R. C., Jortner, B. S., \& Butt, M. T. (2004). Neurotoxicity produced by dibromoacetic acid in drinking water of rats. Toxicol Sci, 79(1), 112-122.

Moser, V. C., Phillips, P. M., McDaniel, K. L., \& MacPhail, R. C. (1999). Behavioral

Moser, V. C., Phillips, P. M., McDaniel, K. L., \& Sills, R. C. (2007). Neurotoxicological evaluation of two disinfection by-products, bromodichloromethane and dibromoacetonitrile, in rats. Toxicology, 230(2-3), 137-144.

Rasmussen;K.M.; Yaktine, A. L. editor. (2009). Weight Gain During Pregnancy: Reexamining the Guidelines__. Committee to Reexamine IOM Pregnancy Weight Guidelines; Institute of Medicine; National Research Council__.

Richardson, S. D., Plewa, M. J., Wagner, E. D., Schoeny, R., \& DeMarini, D. M. (2007). Occurrence, genotoxicity, and carcinogenicity of regulated and emerging disinfection byproducts in drinking water: A review and roadmap for research. Mutation Res, 636(1-3), $178-242$.

Royston, P., \& Wright, E. M. (1998). A method for estimating age-specific reference intervals ('normal ranges') based on fractional polynomials and exponential transformation. $J R$ 
Santa-Marina, L., Ayerdi, M., Lertxundi, A., Basterretxea, M., Goni, F., Inaki, A. J., ... Maria,

Singh, R. (2006). Neuroembryopathic effect of trichloroacetic acid in rats exposed during organogenesis. Birth Defects Res B Dev Reprod Toxicol, 77(1), 47-52.

Spruijt, L., Naviaux, R. K., McGowan, K. A., Nyhan, W. L., Sheean, G., Haas, R. H., \& Barshop, B. A. (2001). Nerve conduction changes in patients with mitochondrial diseases treated with dichloroacetate. Muscle Nerve, 24(7), 916-924.

Stacpoole, P. W., Henderson, G. N., Yan, Z., Cornett, R., \& James, M. O. (1998). Pharmacokinetics, metabolism and toxicology of dichloroacetate. Drug Metab Rev, 30(3), 499-539.

Stacpoole, P. W., Moore, G. W., \& Kornhauser, D. M. (1979). Toxicity of chronic dichloroacetate. N Engl J Med, 300(7), 372.

Villanueva, C. M., Cordier, S., Font-Ribera, L., Salas, L. A., \& Levallois, P. (2015). Overview of disinfection by-products and associated health effects. Curr Environ Health Rep, 2(1), $107-115$.

Villanueva, C. M., Kogevinas, M., Cordier, S., Templeton, M. R., Vermeulen, R., Nuckols, J. R., ... Levallois, P. (2014). Assessing Exposure and Health Consequences of Chemicals in Drinking Water: Current State of Knowledge and Research Needs. Environ Health Perspect, 122(3), 213-221.

Villanueva, C.M., Castaño-Vinyas G, Moreno V, Carrasco-Turigas G, Aragonés N, Boldo E, Ardanaz E, Toledo E, Altzibar JM, Zaldua I, Azpiroz L, Goñi F, Tardón A, Molina AJ, Martín V, López-Rojo C, Jiménez-Moleón JJ, Capelo R, Gómez-Acebo I, Peiró R, Ripoll 
M, Gracia-Lavedan E, Nieuwenhujsen MJ, Rantakokko P, Goslan EH, Pollán M, Kogevinas M. (2012). Concentrations and correlations of disinfection by-products in municipal drinking water from an exposure assessment perspective. Environ Res, 114:1-11.

Villanueva, C.M., Gracia-Lavedán, E., Ibarluzea, J., Santa Marina, L., Ballester, F., Llop, S., Tardón, A., Fernández, M.F., Freire, C., Goñi, F., Basagaña, X., Kogevinas, M., Grimalt, J.O.., Sunyer, J.; INMA (Infancia y Medio Ambiente) Project. (2011) Exposure to trihalomethanes through different water uses and birth weight, small for gestational age, and preterm delivery in Spain. Environ Health Perspect, 119(12):1824-30.

Wechsler, D., \& Kaufman, A. (2001). WAIS-III. Escala de inteligencia de Wechsler para adultos (III). Madrid: TEA Ediciones.

Weinberg, H. S., Pereira, V. R., Singer, P. C., \& Savitz, D. A. (2006). Considerations for improving the accuracy of exposure to disinfection by-products by ingestion in epidemiologic studies. Sci Total Environ, 354(1), 35-42. individual uptake of chloroform: a simulation study. Environ Health Perspect, 111(5), $688-694$. 
1 Table 1. Characteristics of the study population $(n=1855)$.

2

\begin{tabular}{|c|c|c|}
\hline Variable & Categories & $\begin{array}{c}\text { N (\%) I } \\
\text { Median (p25-p75) }\end{array}$ \\
\hline \multirow[t]{4}{*}{ Area } & Asturias & $341(18 \%)$ \\
\hline & Gipuzkoa & $454(24 \%)$ \\
\hline & Sabadell & $475(26 \%)$ \\
\hline & Valencia & $585(32 \%)$ \\
\hline \multicolumn{3}{|l|}{ Child } \\
\hline \multirow[t]{2}{*}{ Sex } & Female & $925(50 \%)$ \\
\hline & Male & $930(50 \%)$ \\
\hline \multirow[t]{3}{*}{ Preterm } & No & $1773(96 \%)$ \\
\hline & Yes & $70(4 \%)$ \\
\hline & Missing & 12 \\
\hline \multirow[t]{3}{*}{ Age at Bayley test (months) } & & $14.3(12.6-15.4)$ \\
\hline & $\leq 14$ months & $706(38 \%)$ \\
\hline & $>14$ months & $1149(62 \%)$ \\
\hline \multirow[t]{3}{*}{ Age at McCarthy test (years) ${ }^{a}$} & & $4.5(4.4-5.6)$ \\
\hline & $<5$ years & $1004(69 \%)$ \\
\hline & $\geq 5$ years & $449(31 \%)$ \\
\hline \multicolumn{3}{|l|}{ Mother } \\
\hline Age (years) & & $31(28-33)$ \\
\hline Height (cm) & & $163(159-167)$ \\
\hline Pre-pregnancy weight (Kg) & & $60(55-67)$ \\
\hline Body mass index $\left(\mathrm{Kg} / \mathrm{m}^{2}\right)$ & & $22.6(20.8-25.1)$ \\
\hline Weight-gain during pregnancy (Kg/week) & & $0.42(0.33-0.51)$ \\
\hline \multirow[t]{2}{*}{ Parity } & 0 & $1057(57 \%)$ \\
\hline & $\geq 1$ & $798(43 \%)$ \\
\hline \multirow[t]{3}{*}{ Social class } & I/II Managers/Technicians & $405(22 \%)$ \\
\hline & III Skilled & $501(27 \%)$ \\
\hline & IV/V Semi-skilled/unskilled & $949(51 \%)$ \\
\hline \multirow[t]{2}{*}{ Country of birth } & Europe & $1749(94 \%)$ \\
\hline & Outside Europe & $106(6 \%)$ \\
\hline \multirow[t]{3}{*}{ Smoking during pregnancy } & No & $1256(69 \%)$ \\
\hline & Yes & $567(31 \%)$ \\
\hline & Missing & 32 \\
\hline \multirow[t]{3}{*}{ Alcohol during pregnancy } & No & $1642(91 \%)$ \\
\hline & Yes, $\geq 1$ drink/week & $165(9 \%)$ \\
\hline & missing & 48 \\
\hline
\end{tabular}


Table 2. Description of water use habits among the study subjects.

\begin{tabular}{|c|c|c|c|c|c|}
\hline Variable & $\begin{array}{c}\text { All } \\
(n=1855)\end{array}$ & $\begin{array}{l}\text { Asturias } \\
(n=341)\end{array}$ & $\begin{array}{c}\text { Gipuzkoa } \\
(n=454)\end{array}$ & $\begin{array}{l}\text { Sabadell } \\
(n=475)\end{array}$ & $\begin{array}{l}\text { Valencia } \\
(n=585)\end{array}$ \\
\hline \multicolumn{6}{|c|}{ Source of drinking water at home (\%) } \\
\hline Bottle & 62 & 52 & 24 & 87 & 75 \\
\hline Tap filtered & 7 & 5 & 11 & 6 & 6 \\
\hline Tap non filtered & 26 & 36 & 64 & 3 & 12 \\
\hline Other & 5 & 7 & 1 & 3 & 8 \\
\hline Missing (n) & 32 & 14 & 12 & 6 & 0 \\
\hline \multicolumn{6}{|c|}{ Source of drinking water outside home (\%) } \\
\hline Bottle & 90 & 90 & 79 & 96 & 93 \\
\hline Tap (non filtered) & 9 & 9 & 21 & 4 & 6 \\
\hline Other & 1 & 1 & 1 & 1 & 1 \\
\hline Missing (n) & 40 & 18 & 13 & 8 & 1 \\
\hline \multicolumn{6}{|l|}{ Tap water ingestion (L/day) ${ }^{a}$} \\
\hline percentile 50 (25-75) & $1.2(0.9-1.8)$ & $1.2(0.6-1.4)$ & $1.2(0.9-1.4)$ & $1.4(0.9-1.8)$ & $1.2(0.9-1.8)$ \\
\hline $\mathrm{n}$ & 474 & 117 & 283 & 13 & 61 \\
\hline \multicolumn{6}{|l|}{ Showering/bathing (\%) } \\
\hline Shower only & 88 & 91 & 94 & 86 & 84 \\
\hline Bath only & 2 & 3 & 2 & 1 & 2 \\
\hline Shower \& bath & 10 & 6 & 5 & 12 & 15 \\
\hline \multicolumn{6}{|l|}{ Shower frequency (times/week) } \\
\hline percentile 50 (25-75) & $7(6-7)$ & $7(7-7)$ & $7(4-7)$ & $7(6-7)$ & $7(5-7)$ \\
\hline $\mathrm{n}$ & 1790 & 318 & 434 & 462 & 576 \\
\hline \multicolumn{6}{|l|}{ Shower duration (min) } \\
\hline percentile 50 (25-75) & $10(7-15)$ & $10(7-15)$ & $10(5-15)$ & $10(7-15)$ & $10(10-15)$ \\
\hline $\mathrm{n}$ & 1789 & 318 & 434 & 462 & 575 \\
\hline \multicolumn{6}{|l|}{ Bath frequency (times/month) } \\
\hline percentile 50 (25-75) & $2(1-3)$ & $2(1-6.5)$ & $2(1-3)$ & $1(1-2)$ & $2(1-3)$ \\
\hline $\mathrm{n}$ & 214 & 28 & 29 & 65 & 92 \\
\hline \multicolumn{6}{|l|}{ Bath duration (min) } \\
\hline percentile 50 (25-75) & $30(20-30)$ & $30(17.5-37.5)$ & $20(15-30)$ & $30(20-30)$ & $30(20-30)$ \\
\hline $\mathrm{n}$ & 215 & 28 & 29 & 64 & 94 \\
\hline
\end{tabular}

${ }^{a}$ Among those drinking unfiltered tap water 
Table 3. Estimated change ${ }^{a}$ in neuropsychological scales from a linear regression for doubling total trihalomethane exposure in average over pregnancy.

\begin{tabular}{|c|c|c|c|c|c|c|c|c|}
\hline Outcome & Exposure & Effect $^{\mathrm{a}}(95 \% \mathrm{Cl})$ & $\mathrm{N}$ & Effect $^{\mathrm{a}}(95 \% \mathrm{Cl})$ & $\mathrm{N}$ & Effect $^{\mathrm{a}}(95 \% \mathrm{Cl})$ & $\mathrm{N}$ & \multirow{2}{*}{$\begin{array}{c}\text { interaction } \\
\mathrm{p} \text {-value }\end{array}$} \\
\hline Mental/co & & All & & Boys & & Girls & & \\
\hline \multicolumn{9}{|l|}{1 year } \\
\hline & Ingestion uptake, $\mu \mathrm{g} /$ day & $-0.07(-0.27,0.13)$ & 1855 & $0.03(-0.25,0.32)$ & 930 & $-0.15(-0.43,0.13)$ & 925 & 0.89 \\
\hline & All route uptake $\mathrm{e}^{\mathrm{b}}, \mu \mathrm{g} /$ day & $0.00(-0.47,0.46)$ & 1823 & $-0.42(-1.10,0.25)$ & 916 & $0.42(-0.22,1.07)$ & 907 & 0.07 \\
\hline & Residential levels, $\mu \mathrm{g} / \mathrm{L}$ & $0.09(-0.49,0.66)$ & 1855 & $-0.76(-1.59,0.07)$ & 930 & $0.88(0.09,1.68)$ & 925 & 0.02 \\
\hline \multicolumn{9}{|l|}{$4-5$ years } \\
\hline & Residential levels, $\mu \mathrm{g} / \mathrm{L}$ & $-0.35(-0.96,0.25)$ & 1453 & $-0.59(-1.50,0.32)$ & 719 & $-0.09(-0.91,0.73)$ & 734 & 0.78 \\
\hline \multicolumn{9}{|c|}{ Motor score } \\
\hline \multirow[t]{3}{*}{1 year } & Ingestion uptake, $\mu \mathrm{g} /$ day & $-0.07(-0.26,0.11)$ & 1855 & $0.02(-0.24,0.28)$ & 930 & $-0.14(-0.42,0.13)$ & 925 & 0.52 \\
\hline & All route uptake ${ }^{b}, \mu \mathrm{g} /$ day & $-0.05(-0.49,0.38)$ & 1823 & $-0.24(-0.85,0.37)$ & 916 & $0.22(-0.41,0.85)$ & 907 & 0.46 \\
\hline & Residential levels, $\mu \mathrm{g} / \mathrm{L}$ & $0.00(-0.54,0.53)$ & 1855 & $-0.66(-1.41,0.08)$ & 930 & $0.69(-0.09,1.48)$ & 925 & 0.16 \\
\hline & Residential levels, $\mu \mathrm{g} / \mathrm{L}$ & $0.01(-0.62,0.64)$ & 1453 & $-0.60(-1.55,0.36)$ & 719 & $0.65(-0.18,1.48)$ & 734 & 0.01 \\
\hline
\end{tabular}

${ }^{a}$ Additive change in the mean of the outcome when doubling the exposure, from a linear regression adjusted for area, age at examination, sex, psychologist, quality of the test, parity and maternal age, social class, born in Europe, alcohol and smoking during pregnancy, height, prepregnancy body mass index and weight gain during pregnancy.

${ }^{b}$ All route uptake is the total residential THM uptake through ingestion, showering and bathing. 
Table 4. Estimated change ${ }^{a}$ in neuropsychological scales from a linear regression for doubling exposure in average over pregnancy.

\begin{tabular}{|c|c|c|c|c|c|c|c|c|c|}
\hline Outcome & Exposure metric & $\begin{array}{l}\text { THM } \\
\text { component }\end{array}$ & Effect $^{\mathrm{a}}(95 \% \mathrm{Cl})$ & $\mathrm{N}$ & Effect $^{\mathrm{a}}(95 \% \mathrm{Cl})$ & $\mathrm{N}$ & Effect $^{\mathrm{a}}(95 \% \mathrm{Cl})$ & $\mathrm{N}$ & \\
\hline \multicolumn{2}{|c|}{ Mental/cognitive score } & & All & & Boys & & Girls & & $p$-value \\
\hline \multirow[t]{6}{*}{1 year } & \multirow[t]{2}{*}{ Ingestion uptake, $\mu \mathrm{g} /$ day } & Chloroform & $-0.06(-0.25,0.12)$ & 1855 & $0.03(-0.24,0.30)$ & 930 & $-0.14(-0.41,0.12)$ & 925 & 0.62 \\
\hline & & Brominated & $-0.10(-0.33,0.14)$ & 1855 & $0.03(-0.30,0.36)$ & 930 & $-0.19(-0.52,0.13)$ & 925 & 0.58 \\
\hline & \multirow[t]{2}{*}{ All route uptake ${ }^{b}, \mu g /$ day } & Chloroform & $0.06(-0.24,0.37)$ & 1823 & $-0.19(-0.64,0.25)$ & 916 & $0.31(-0.12,0.73)$ & 907 & 0.01 \\
\hline & & Brominated & $0.01(-0.49,0.51)$ & 1823 & $-0.38(-1.11,0.34)$ & 916 & $0.39(-0.29,1.08)$ & 907 & 0.43 \\
\hline & \multirow[t]{2}{*}{ Residential levels, $\mu \mathrm{g} / \mathrm{L}$} & Chloroform & $0.12(-0.20,0.44)$ & 1855 & $-0.24(-0.70,0.22)$ & 930 & $0.44(-0.01,0.89)$ & 925 & $<0.01$ \\
\hline & & Brominated & $0.13(-0.46,0.72)$ & 1855 & $-0.64(-1.49,0.21)$ & 930 & $0.84(0.02,1.66)$ & 925 & 0.24 \\
\hline \multirow[t]{6}{*}{ 4-5 years } & \multirow[t]{2}{*}{ Ingestion uptake, $\mu \mathrm{g} / \mathrm{day}$} & Chloroform & $0.17(-0.03$ & 1453 & $0.22(-0.07,0.51)$ & 719 & $0.11(-0.16,0.38)$ & 734 & 0.03 \\
\hline & & Brominated & $0.18(-0.05,0.42)$ & 1453 & $0.20(-0.15,0.55)$ & 719 & $0.16(-0.17,0.49)$ & 734 & 0.12 \\
\hline & \multirow[t]{2}{*}{ All route uptake ${ }^{b}, \mu g /$ day } & Chloroform & $-0.26(-0.58,0.06)$ & 1429 & $-0.34(-0.82,0.13)$ & 708 & $-0.17(-0.61,0.26)$ & 721 & 0.34 \\
\hline & & Brominated & $-0.64(-1.16,-0.12)$ & 1429 & $-0.62(-1.39,0.16)$ & 708 & $-0.64(-1.34,0.06)$ & 721 & 0.84 \\
\hline & \multirow[t]{2}{*}{ Residential levels, $\mu \mathrm{g} / \mathrm{L}$} & Chloroform & $-0.16(-0.50$ & 1453 & $-0.33(-0.83,0$ & 719 & $0.01(-0.44,0.46)$ & 734 & 0.49 \\
\hline & & Brom & $-0.39(-1.01,0.24)$ & 1453 & $-0.65(-1.59,0.28)$ & 719 & $-0.09(-0.93,0.75)$ & 734 & 0.87 \\
\hline \multicolumn{10}{|l|}{ Motor scale } \\
\hline \multirow[t]{6}{*}{1 year } & \multirow[t]{2}{*}{ Ingestion uptake, $\mu \mathrm{g} / \mathrm{day}$} & Chloroform & $-0.07(-0.25,0.10)$ & 1855 & $0.00(-0.24,0.24)$ & 930 & $-0.12(-0.38,0.14)$ & 925 & 0.70 \\
\hline & & Brominated & $-0.08(-0.29,0.14)$ & 1855 & $0.01(-0.29,0.31)$ & 930 & $-0.14(-0.46,0.18)$ & 925 & 0.36 \\
\hline & \multirow[t]{2}{*}{ All route uptake ${ }^{b}, \mu g /$ day } & Chloroform & $-0.05(-0.34,0.23)$ & 1823 & $-0.27(-0.67,0.13)$ & 916 & $0.20(-0.22,0.61)$ & 907 & 0.10 \\
\hline & & Brominated & $-0.06(-0.53,0.41)$ & 1823 & $-0.25(-0.90,0.40)$ & 916 & $0.20(-0.47,0.87)$ & 907 & 0.82 \\
\hline & \multirow[t]{2}{*}{ Residential levels, $\mu \mathrm{g} / \mathrm{L}$} & Chloroform & $-0.02(-0.32,0.28)$ & 1855 & $-0.37(-0.79,0.04)$ & 930 & $0.34(-0.09,0.78)$ & 925 & 0.04 \\
\hline & & Brominated & $-0.01(-0.56,0.55)$ & 1855 & $-0.70(-1.47,0.06)$ & 930 & $0.72(-0.08,1.53)$ & 925 & 0.36 \\
\hline \multirow[t]{6}{*}{$4-5$ years } & \multirow[t]{2}{*}{ Ingestion uptake, $\mu \mathrm{g} / \mathrm{day}$} & Chloroform & $0.08(-0.13,0.28)$ & 1453 & $0.02(-0.28,0.32)$ & 719 & $0.18(-0.09,0.45)$ & 734 & 0.45 \\
\hline & & Brominated & $0.05(-0.20,0.30)$ & 1453 & $-0.04(-0.41,0.33)$ & 719 & $0.19(-0.14,0.52)$ & 734 & 0.26 \\
\hline & \multirow[t]{2}{*}{ All route uptake ${ }^{b}, \mu g /$ day } & Chloroform & $0.01(-0.32,0.34)$ & 1429 & $-0.22(-0.72,0.29)$ & 708 & $0.23(-0.21,0.66)$ & 721 & 0.09 \\
\hline & & Brominated & $-0.30(-0.85,0.24)$ & 1429 & $-0.27(-1.10,0.55)$ & 708 & $-0.29(-1.00,0.42)$ & 721 & 0.17 \\
\hline & \multirow[t]{2}{*}{ Residential levels, $\mu \mathrm{g} / \mathrm{L}$} & Chloroform & $0.07(-0.28,0.42)$ & 1453 & $-0.29(-0.82,0.23)$ & 719 & $0.42(-0.04,0.88)$ & 734 & 0.03 \\
\hline & & Brominated & $-0.10(-0.75,0.55)$ & 1453 & $-0.58(-1.57,0.41)$ & 719 & $0.42(-0.43,1.28)$ & 734 & 0.02 \\
\hline
\end{tabular}


${ }^{a}$ Additive change in the mean of the outcome when doubling the exposure, from a linear regression adjusted for area, age at examination, sex, psychologist, quality of the test, parity and maternal age, social class, born in Europe, alcohol and smoking during pregnancy, height, prepregnancy body mass index and weight gain during pregnancy.

${ }^{\mathrm{b}}$ All route uptake is the total residential THM uptake through ingestion, showering and bathing. 
Table 5. Estimated change ${ }^{a}$ in neuropsychologial scales from a linear regression for doubling residential haloacetic acid levels ( $\left.\mu \mathrm{g} / \mathrm{L}\right)$ in average over pregnancy.

\begin{tabular}{|c|c|c|c|c|c|c|c|c|}
\hline Outcome & Exposure & Effect $^{\mathrm{a}}(95 \% \mathrm{Cl})$ & $\mathrm{N}$ & Effect $^{\mathrm{a}}(95 \% \mathrm{Cl})$ & $\mathrm{N}$ & Effect $^{\mathrm{a}}(95 \% \mathrm{Cl})$ & $\mathrm{N}$ & Interaction \\
\hline & & All & & Boys & & Girls & & $p$-value \\
\hline \multicolumn{9}{|c|}{ Mental/cognitive score } \\
\hline \multirow{2}{*}{1 year } & Trichloroacetic acid & $0.90(-1.63,3.43)$ & 454 & $-0.31(-3.91,3.30)$ & 215 & $2.07(-1.54,5.69)$ & 239 & 0.27 \\
\hline & Total haloacetic acids & $2.54(-0.23,5.32)$ & 454 & $0.60(-3.43,4.63)$ & 215 & $3.96(0.05,7.87)$ & 239 & 0.10 \\
\hline \multirow{2}{*}{$4-5$ years } & Trichloroacetic acid & $-0.33(-3.31,2.65)$ & 313 & $1.26(-3.44,5.96)$ & 146 & $-1.63(-5.78,2.53)$ & 167 & 0.32 \\
\hline & Total haloacetic acids & $0.58(-2.33,3.48)$ & 313 & $1.26(-3.23,5.75)$ & 146 & $0.45(-3.77,4.66)$ & 167 & 0.68 \\
\hline \multicolumn{9}{|c|}{ Motor score } \\
\hline 1 year & Dichloroacetic acid & $-0.57(-2.43,1.28)$ & 454 & $1.04(-1.63,3.71)$ & 215 & $-2.41(-5.08,0.26)$ & 239 & 0.54 \\
\hline \multirow[t]{3}{*}{$4-5$ years } & Dichloroacetic acid & $-0.75(-2.55,1.05)$ & 313 & $-1.29(-4.24,1.67)$ & 146 & $0.08(-2.38,2.55)$ & 167 & 0.48 \\
\hline & Trichloroacetic acid & $0.26(-2.87,3.39)$ & 313 & $-0.68(-5.92,4.56)$ & 146 & $1.26(-2.86,5.38)$ & 167 & 0.65 \\
\hline & Total haloacetic acids & $-1.58(-4.63,1.46)$ & 313 & $-2.24(-7.24,2.75)$ & 146 & $-0.65(-4.83,3.52)$ & 167 & 0.70 \\
\hline
\end{tabular}

${ }^{a}$ Additive change in the mean of the outcome when doubling the exposure, from a linear regression adjusted for area, age at examination, sex, psychologist, quality of the test, parity and maternal age, social class, born in Europe, alcohol and smoking during pregnancy, height, prepregnancy body mass index and weight gain during pregnancy.

${ }^{b}$ All route uptake is the total residential THM uptake through ingestion, showering and bathing. 
Figure 1. Distribution of the modeled exposures evaluated among the study areas. Boxes are delimited by the 25th (left hinge) and 75th (right hinge) percentiles, the central vertical line represents the median value, the whiskers represent \pm 1.5 times the interquartile range, and the points outside the whiskers represent outliers.

All route uptake is the total residential THM uptake through ingestion, showering and bathing. 
Figure 2. Distribution of the neuropsychological scores at 1 year (Bayley Scales of Infant Development) and 4-5 years (McCarthy Scales of Children's Abilities) in the study population.

Footnote: Only the standardized scores were used in the multivariate models to estimate the association with the exposure. 
Figure 3. Exposure-response relationship between log-transformed brominated trihalomethane (THM) uptake through all routes and general cognitive score at 4-5 years. Smoothed spline with 3 degrees of freedom from general additive models adjusted for area, age at examination, sex, psychologist, quality of the test, parity and maternal age, social class, born in Europe, alcohol and smoking during pregnancy, height, pre-pregnancy body mass index and weight gain during pregnancy. P-value for gain compared to linear model: 0.09

\footnotetext{
${ }^{a}$ Additive change in the mean of the outcome when doubling the exposure.

${ }^{\mathrm{b}}$ All route uptake is the total residential THM uptake through ingestion, showering and bathing.
} 


\section{SUPPLEMENTAL MATERIAL}

\section{Drinking water disinfection by-products during pregnancy and child neuropsychological development in the INMA Spanish cohort study}

Cristina M Villanueva, Esther Gracia-Lavedan, Jordi Julvez, Loreto Santa-Marina, Nerea Lertxundi, Jesús Ibarluzea, Sabrina Llop, Ferran Ballester, Ana FernándezSomoano, Adonina Tardón, Martine Vrijheid, Mònica Guxens, Jordi Sunyer

Study area

Supplemental Material, Figure S1. Number of total THM measurements (number of sampling locations from own sampling) in the study municipalities, by area. ................................... 3

Experimental trihalomethane and haloacetic acid analysis in tap water ............................. 4

Procedure to model trihalomethane and haloacetic acid levels ................................... 4

Supplemental Material, Table S1. Uptake factors from the literature and values used in this study.

Supplemental Material, Figure S2. Flow chart of the study population included in the analyses.

Supplemental Material, Table S2. Spearman's rank correlation coefficients between haloacetic acids and trihalomethanes.

Supplemental Material, Table S3. Estimated change in neuropsychological scales from a linear regression for doubling exposure to total trihalomethane (THM) exposure by trimester of gestation.

Supplemental material, Figure S3. General additive models showing the association ${ }^{a}$ between log-transformed trihalomethane (THM) exposure variables and neuropsychologial outcomes at 1 and 4-5 years. P-values for gain compared to the linear model are shown in each graph.

Supplemental Material, Table S4. Estimated change in neuropsychological scales from a linear regression for doubling exposure to total trihalomethanes in average over pregnancy, by cohort.

Supplemental Material, Table S5. Estimated change in neuropsychologial scales from a linear regression for doubling total trihalomethane exposure in average over pregnancy, by maternal social class. 
Study area

The study area in the Asturias cohort comprises 9 municipalities (Avilés, Castrillón, Corvera, Gozón, Muros de Nalón, Pravia, Cudillero, Soto del Barco and Illas) accounting for approximately 160.000 inhabitants in 2010, supplied by surface water through 11 distribution networks. The Gipuzkoa cohort comprises 2 counties (Goierri, Alto Urola) with 25 municipalities and 90.000 inhabitants, supplied by surface water from 3 reservoirs through 26 distribution networks. The Sabadell cohort is comprised by a single municipality with approximately 200.000 inhabitants and a single water distribution network from a surface source. The Valencia cohort includes 34 municipalities and part of Valencia City, accounting for approximately 300.000 inhabitants supplied with water from different sources (surface, ground and mixed) and 70 distribution networks. Chlorine is the main disinfectant used in all the study areas during the study period. 
Supplemental Material, Figure S1. Number of total THM measurements (number of sampling locations from own sampling) in the study municipalities, by area.

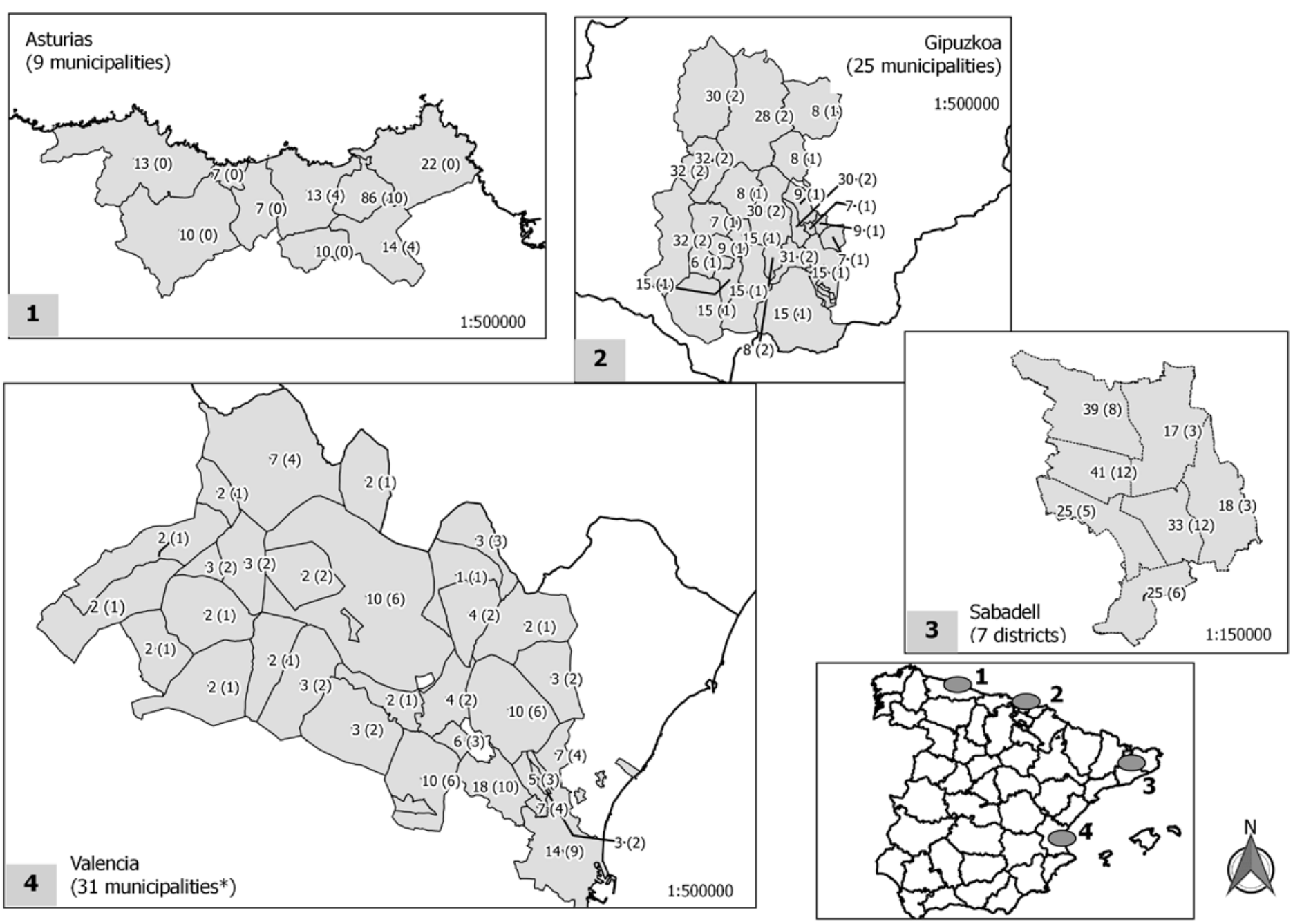

* From the 34 municipalities, 3 were excluded from the analysis due to atypical values excluded from 3 municipalities. NOTE: In Asturias, only data from routine monitoring was used in 6 municipalities. 


\section{Experimental trihalomethane and haloacetic acid analysis in tap water}

Samples for THM analyses were collected in $40 \mathrm{ml}$ glass vials with $5 \mathrm{mg}$ of sodium thiosulphate, avoiding bubble formation. The vials were sealed with Teflon-faced rubber septa and open-top screw plugs. Chloroform, bromodichloromethane, dibromochloromethane, and bromoform were measured using purge-and-trap gas chromatography/mass spectrometry (GC/MS). Samples for haloacetic acid analysis were collected in $50 \mathrm{ml}$ amber glass containers with $125 \mu \mathrm{l}$ ammonium chloride at $4 \%$. Experimental analysis followed the 552.3 EPA method, using a mass spectrometer operated in negative chemical ionization. All samples were stored and shipped to the laboratory in cold temperature $\left(\sim 4^{\circ} \mathrm{C}\right)$.

\section{Procedure to model trihalomethane and haloacetic acid levels}

In a first stage, bivariate descriptive analyses were conducted to identify the variables influencing THM and HAA levels: sampling month and year, geographical variable (municipality, district, sampling site, UTM coordinate), water source (ground, surface, mixed), source of data (own sampling, regulatory data). Secondly, variables were transformed when necessary to obtain a normal distribution and bivariate linear regressions were conducted. Variables associated with the levels with statistical significance $(p$-value $<0.05)$ or variables a priori relevant were included simultaneously in linear regression models and generalized additive models (GAMs). GAM models were used to fit a smoothed function of month that was used to predict levels for months without observations and also a smooth function of coordinates. Both the R-squared and the Akaike information criteria were used to select the final model. The models with highest R2 and lowest AIC were selected. We run separate models for total THMs, chloroform ( $\mathrm{CHCl} 3)$, bromodichloromethane $(\mathrm{CHBrCl} 2)$, dibromochloromethane $(\mathrm{CHBr} 2 \mathrm{Cl})$, bromoform $(\mathrm{CHBr} 3)$, total HAAs, dichloracetic acid (DCAA) and trichloroacetic acid (TCAA). Non-significant variables were discarded and relevant variables for temporal or geographical variability were tested and retained if appeared to be statistically significant. Final models were: 


\begin{tabular}{|c|c|c|c|c|}
\hline $\begin{array}{l}\text { Chemical/ } \\
\text { cohort }\end{array}$ & model & $\begin{array}{c}\text { Transformation of } \\
\text { dependent variable }\end{array}$ & Variables & $\mathrm{R} 2$ \\
\hline \multicolumn{5}{|l|}{ Total THM } \\
\hline Asturias & GAM & Squared root & $\mathrm{s}$ (month), water source ${ }^{\mathrm{a}}$, municipality & 0.448 \\
\hline Gipuzkoa & GAM & - & $\mathrm{s}$ (month), year, sampling site & 0.685 \\
\hline Sabadell & GAM & Logarithm & $\mathrm{s}(\text { coordinates })^{b}, \mathrm{~s}$ (month) & 0.506 \\
\hline Valencia & GAM & Logarithm & $\mathrm{s}$ (month), municipality ${ }^{\mathrm{c}}$ & 0.809 \\
\hline \multicolumn{5}{|l|}{$\mathrm{CHCl} 3$} \\
\hline Asturias & GAM & Square root & $\mathrm{s}$ (month), water source ${ }^{\mathrm{a}}$, municipality & 0.530 \\
\hline Gipuzkoa & GAM & Square root & s(month), year, sampling site & 0.693 \\
\hline Sabadell & GAM & Squared root & s(coordinates) ${ }^{b}$, Month, year & 0.391 \\
\hline Valencia & GAM & Logarithm & s(month), municipality ${ }^{c}$ & 0.838 \\
\hline \multicolumn{5}{|l|}{$\mathrm{CHCl} 2 \mathrm{Br}$} \\
\hline Asturias & GAM & Squared root & $\mathrm{s}$ (month), water source ${ }^{\mathrm{a}}$, municipality & 0.244 \\
\hline Gipuzkoa & GAM & - & s(month), sampling.site & 0.721 \\
\hline Sabadell & GAM & Squared root & $\mathrm{s}(\text { coordinates })^{b}, \mathrm{~s}$ (month) & 0.295 \\
\hline Valencia & GAM & Logarithm & $\mathrm{s}$ (month), municipality ${ }^{\mathrm{c}}$ & 0.817 \\
\hline \multicolumn{5}{|l|}{$\mathrm{CHClBr} 2$} \\
\hline Asturias & GAM & Squared root & s(month), year, municipality & 0.331 \\
\hline Gipuzkoa & Linear & - & Sampling site & 0.670 \\
\hline Sabadell & GAM & Squared root & $\mathrm{s}$ (coordinates) $)^{b}$, Month, year & 0.563 \\
\hline Valencia & GAM & Logarithm & $\mathrm{s}$ (month), municipality ${ }^{\mathrm{c}}$ & 0.792 \\
\hline \multicolumn{5}{|l|}{$\mathrm{CHBr3}$} \\
\hline Asturias & GAM & Squared root & s(month), year, municipality & 0.469 \\
\hline Gipuzkoa & GAM & Logarithm & $\mathrm{s}$ (month), year, sampling site & 0.551 \\
\hline Sabadell & GAM & ()$^{\wedge / 4}$ & $\mathrm{~s}\left(\right.$ coordinates) ${ }^{\mathrm{b}}$, Month & 0.468 \\
\hline Valencia & GAM & Logarithm & $\mathrm{s}$ (month), municipality ${ }^{\mathrm{c}}$ & 0.786 \\
\hline Total HAAs & GAM & Squared root & $\mathrm{s}$ (month), s(year), sampling site & 0.527 \\
\hline DCAA & GAM & Squared root & $\mathrm{s}$ (month), s(year), sampling site & 0.737 \\
\hline TCAA & GAM & Logarithm & s(month), sampling site & 0.425 \\
\hline
\end{tabular}

$\mathrm{s}($ variable $)=$ smoothed function

a 2 categories: surface, mixed.

${ }^{\mathrm{b}}$ UTM coordinates of the residence from all study subjects were available only in Sabadell.

${ }^{c}$ Large municipalities in Valencia had more than one category, corresponding to different water zones (49 categories).

We used personal information of the study subjects (address, conception date) to create personal indices of THM and HAA levels based on address of residence (municipality, sampling site, UTM coordinate, water source), gestation month and/or year using the previously built models. We estimated levels at the residence by month of pregnancy and estimated the average by trimester and overall pregnancy. 
Supplemental Material, Table S1. Uptake factors from the literature and values used in this study.

\begin{tabular}{|c|c|c|c|c|c|c|}
\hline Compound & \multicolumn{2}{|l|}{ Ingestion } & \multicolumn{2}{|c|}{ Showering } & \multicolumn{2}{|l|}{ Bathing } \\
\hline \multicolumn{7}{|c|}{ Uptake factors based on the literature $^{a}$} \\
\hline & $\begin{array}{c}\text { Uptake factor } \\
(\mu \mathrm{g} / \mu \mathrm{g} / \mathrm{l})\end{array}$ & Ref. & $\begin{array}{l}\text { Uptake factor } \\
(\mu \mathrm{g} / \mathrm{min} / \mu \mathrm{g} / \mathrm{l})\end{array}$ & Ref. & $\begin{array}{l}\text { Uptake factor } \\
(\mu \mathrm{g} / \mathrm{min} / \mu \mathrm{g} / \mathrm{l})\end{array}$ & Ref. \\
\hline $\mathrm{CHCl} 3$ & 0.004901961 & $(1)$ & 0.001536261 & $(1,2)$ & 0.001320755 & (1) \\
\hline $\mathrm{CHCl} 2 \mathrm{Br}$ & 0.001086957 & (1) & 0.001315092 & $(1,2)$ & 0.001189711 & (1) \\
\hline $\mathrm{CHClBr} 2$ & 0.00115 & $(1)$ & 0.001389034 & $(1,2)$ & 0.001401709 & (1) \\
\hline $\mathrm{CHBr} 3$ & - & & 0.000437931 & (2) & - & \\
\hline \multicolumn{7}{|c|}{ Uptake factors used in the present analysis $^{b}$} \\
\hline $\mathrm{CHCl} 3$ & 0.00490196 & & 0.00153626 & & 0.00132075 & \\
\hline $\begin{array}{c}\text { Brominated } \\
\text { THM }\end{array}$ & 0.00111848 & & 0.00135206 & & 0.00129571 & \\
\hline
\end{tabular}

a. Values obtained from studies reporting blood THM levels after drinking, showering and bathing. For each study, water use and THM chemical, blood concentration was calculated for a given concentration in the water and liters of water ingested or duration of showering/bathing. Information was obtained either directly from the published paper or personal communication with the authors. When more than one factor was obtained for a given THM and water use, an average was calculated.

b. Brominated THM uptake factors are the average of bromodichloromethane and dibromochloromethane (and also bromoform for showering).

References:

1) Backer LC, Ashley DL, Bonin MA, Cardinali FL, Kieszak SM, Wooten JV. 2000. Household exposures to drinking water disinfection by-products: whole blood trihalomethane levels. J Expo Anal Environ Epidemiol 10:321-326.

2) Lynberg M, Nuckols JR, Langlois $P$, Ashley D, Singer $P$, Mendola $P$ et al. 2001. Assessing exposure to disinfection by-products in women of reproductive age living in Corpus Christi, Texas, and Cobb County, Georgia: descriptive results and methods. Environ Health Perspect 109:597604. 
Supplemental Material, Figure S2. Flow chart of the study population included in the analyses.

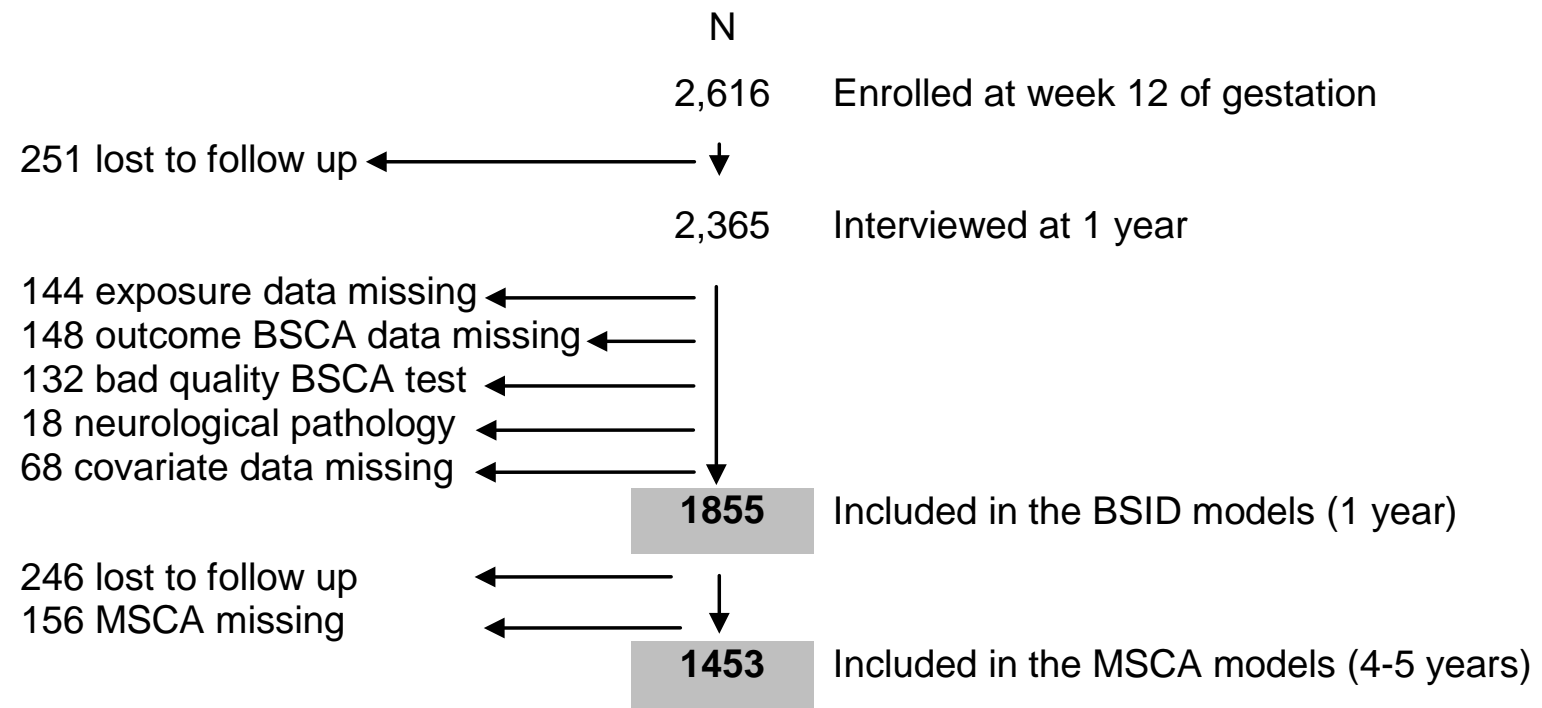


Supplemental Material, Table S2. Spearman's rank correlation coefficients between haloacetic acids and trihalomethanes.

\begin{tabular}{rcccc}
\hline Trihalomethanes (THMs) & $\begin{array}{c}\text { Dichloroacetic } \\
\text { acid }\end{array}$ & $\begin{array}{c}\text { Trichloroacetic } \\
\text { acid }\end{array}$ & $\begin{array}{c}\text { Total haloacetic } \\
\text { acids }\end{array}$ & $\mathrm{N}$ \\
\hline Levels, $\mu \mathrm{g} / \mathrm{L}$ & & & & \\
\hline Total THMs & $0.47^{\star \star \star}$ & $0.83^{\star \star \star}$ & $0.68^{\star \star \star}$ & 454 \\
Chloroform & $0.51^{\star \star \star}$ & $0.85^{\star \star \star}$ & $0.61^{\star \star \star}$ & 454 \\
Brominated THMs & $0.30^{\star \star *}$ & $0.63^{\star \star \star}$ & $0.57^{\star \star \star}$ & 454 \\
\hline All route uptake ${ }^{\mathrm{a}}, \mu \mathrm{g} /$ day & & & & \\
\hline Total THMs & $0.26^{\star \star \star}$ & $0.41^{\star \star \star}$ & $0.37^{\star \star \star}$ & 442 \\
Chloroform & $0.32^{\star \star \star}$ & $0.50^{\star \star \star}$ & $0.39^{\star \star \star}$ & 442 \\
Brominated THMs & $0.15^{\star \star}$ & $0.25^{\star \star \star}$ & $0.29^{\star \star \star}$ & 442 \\
\hline Ingestion uptake, $\mu$ g/day & & & & 454 \\
\hline Total THMs & $0.12^{\star}$ & $0.21^{\star \star \star}$ & $0.16^{\star \star \star}$ & 454 \\
Chloroform & $0.14^{\star \star}$ & $0.23^{\star \star \star}$ & $0.18^{\star \star \star}$ & 454 \\
\hline
\end{tabular}

*p-value $<0.05$ **p-value $<0.01{ }^{* * *}$ p-value $<0.001$

${ }^{a}$ All route uptake is the total residential THM uptake through ingestion, showering and bathing. 
Supplemental Material, Table S3. Estimated change ${ }^{a}$ in neuropsychological scales from a linear regression for doubling exposure to total trihalomethane (THM) exposure by trimester of gestation.

\begin{tabular}{|c|c|c|c|c|c|}
\hline Outcome & Exposure & $\begin{array}{c}\text { Effect }^{\mathrm{a}}(95 \% \mathrm{Cl}) \\
1 \text { rst trimester }\end{array}$ & $\begin{array}{c}\text { Effect }^{\mathrm{a}}(95 \% \mathrm{Cl}) \\
\text { 2nd trimester }\end{array}$ & $\begin{array}{c}\text { Effect }^{\mathrm{a}}(95 \% \mathrm{Cl}) \\
\text { 3rd trimester }\end{array}$ & $\mathrm{N}$ \\
\hline \multicolumn{6}{|c|}{ Mental/cognitive score } \\
\hline 1 year & Ingestion THM uptake ( $\mu \mathrm{g} /$ day) & $-0.06(-0.26,0.13)$ & $-0.07(-0.27,0.13)$ & $-0.05(-0.23,0.14)$ & 1855 \\
\hline $4-5$ years & Ingestion THM uptake ( $\mu \mathrm{g} /$ day) & $0.16(-0.04,0.36)$ & $0.18(-0.03,0.38)$ & $0.18(-0.01,0.37)$ & 1453 \\
\hline \multicolumn{6}{|c|}{ Motor score } \\
\hline 1 year & Ingestion THM uptake ( $\mu \mathrm{g} /$ day) & $-0.07(-0.25,0.12)$ & $-0.08(-0.26,0.11)$ & $-0.04(-0.21,0.14)$ & 1855 \\
\hline $4-5$ years & Ingestion THM uptake ( $\mu \mathrm{g} / \mathrm{day})$ & $0.05(-0.16,0.26)$ & $0.06(-0.15,0.26)$ & $0.08(-0.12,0.27)$ & 1453 \\
\hline \multicolumn{6}{|c|}{ Mental score } \\
\hline 1 year & All route THM uptake ${ }^{b}(\mu \mathrm{g} /$ day $)$ & $-0.02(-0.48,0.45)$ & $0.03(-0.43,0.48)$ & $0.00(-0.46,0.46)$ & 1823 \\
\hline $4-5$ years & All route THM uptake ${ }^{b}(\mu \mathrm{g} /$ day $)$ & $-0.59(-1.07,-0.1)$ & $-0.48(-0.96,-0.01)$ & $-0.52(-1.00,-0.04)$ & 1429 \\
\hline \multicolumn{6}{|c|}{ Motor score } \\
\hline 1 year & All route THM uptake ${ }^{b}(\mu \mathrm{g} /$ day $)$ & $-0.11(-0.55,0.33)$ & $-0.06(-0.48,0.37)$ & $0.02(-0.42,0.45)$ & 1823 \\
\hline $4-5$ years & All route THM uptake ${ }^{\mathrm{b}}(\mu \mathrm{g} / \mathrm{day})$ & $-0.15(-0.65,0.36)$ & $-0.13(-0.63,0.36)$ & $-0.18(-0.68,0.33)$ & 1429 \\
\hline
\end{tabular}

${ }^{a}$ Additive change in the mean of the outcome when doubling the exposure from a linear regression adjusted for area, age at examination, sex, psychologist, quality of the test, parity and maternal age, social class, born in Europe, alcohol and smoking during pregnancy, height, prepregnancy body mass index and weight gain during pregnancy.

${ }^{b}$ All route uptake is the total residential THM uptake through ingestion, showering and bathing. 
Supplemental material, Figure S3. General additive models showing the association ${ }^{a}$ between log-transformed trihalomethane (THM) exposure variables and neuropsychologial outcomes at 1 and 4-5 years. P-values for gain compared to the linear model are shown in each graph.
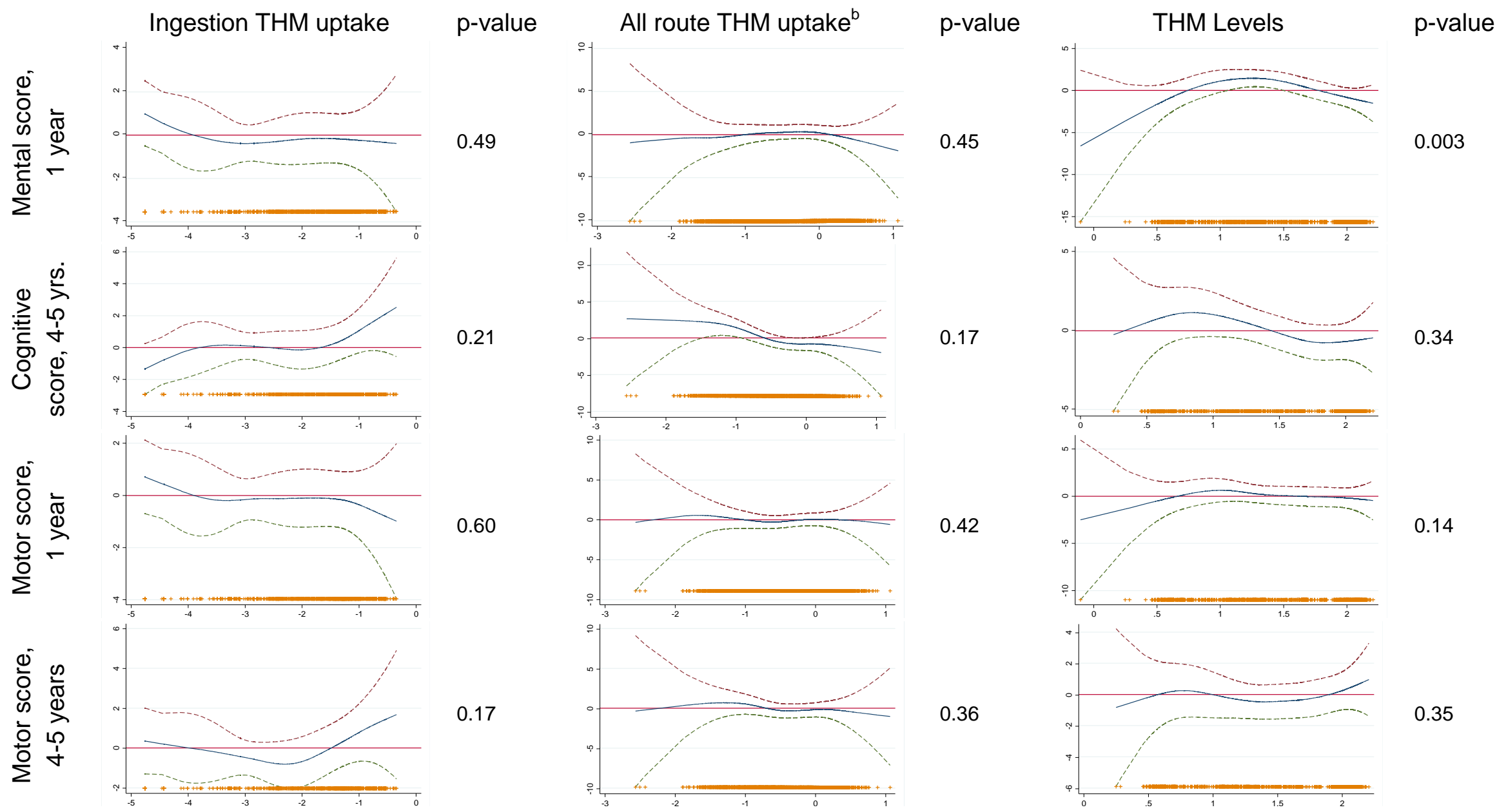

${ }^{\text {a }}$ Additive change in the mean of the outcome when doubling the exposure, from a linear regression adjusted for area, age at examination, sex, psychologist, quality of the test, parity and maternal age, social class, born in Europe, alcohol and smoking during pregnancy, height, prepregnancy body mass index and weight gain during pregnancy.

${ }^{b}$ All route uptake is the total residential THM uptake through ingestion, showering and bathing. 
Supplemental Material, Table S4. Estimated change ${ }^{a}$ in neuropsychological scales from a linear regression for doubling exposure to total trihalomethanes in average over pregnancy, by cohort.

\begin{tabular}{|c|c|c|c|c|c|}
\hline \multirow[t]{2}{*}{ Outcome } & \multirow[t]{2}{*}{ Area } & \multirow{2}{*}{$\begin{array}{l}\text { Effect }^{\mathrm{a}}(95 \% \mathrm{Cl}) \\
\text { Ingestion THM } \\
\text { uptake ( } \mu \mathrm{g} / \text { day })\end{array}$} & $\mathrm{N}$ & \multirow{2}{*}{$\begin{array}{c}\text { Effect }^{\mathrm{a}}(95 \% \mathrm{Cl}) \\
\text { All route THM } \\
\text { uptake }^{\mathrm{b}}(\mu \mathrm{g} / \text { day })\end{array}$} & \multirow{2}{*}{$\begin{array}{c}\mathrm{N} \\
1724\end{array}$} \\
\hline & & & 1749 & & \\
\hline \multicolumn{6}{|c|}{$\begin{array}{l}\text { Mental/cognitive } \\
\text { score }\end{array}$} \\
\hline \multirow[t]{4}{*}{1 year } & Asturias & $-0.05(-0.58,0.49)$ & 341 & $-1.75(-3.47,-0.04)$ & 327 \\
\hline & Gipuzkoa & $0.09(-0.33,0.51)$ & 454 & $1.28(-0.26,2.82)$ & 442 \\
\hline & Sabadell & $0.14(-0.41,0.68)$ & 475 & $-0.92(-2.72,0.87)$ & 469 \\
\hline & Valencia & $-0.18(-0.48,0.11)$ & 585 & $0.07(-0.49,0.62)$ & 585 \\
\hline \multirow[t]{4}{*}{$4-5$ years } & Asturias & $0.21(-0.29,0.71)$ & 308 & $-1.05(-2.73,0.63)$ & 297 \\
\hline & Gipuzkoa & $-0.15(-0.65,0.34)$ & 313 & $-2.12(-3.97,-0.28)$ & 305 \\
\hline & Sabadell & $0.57(0.05,1.09)$ & 395 & $-0.39(-2.19,1.40)$ & 390 \\
\hline & Valencia & $0.11(-0.19,0.41)$ & 437 & $-0.36(-0.94,0.22)$ & 437 \\
\hline \multicolumn{6}{|c|}{ Motor score } \\
\hline \multirow[t]{4}{*}{1 year } & Asturias & $-0.50(-0.96,-0.03)$ & 341 & $-0.71(-2.21,0.79)$ & 327 \\
\hline & Gipuzkoa & $0.01(-0.46,0.47)$ & 454 & $0.76(-0.96,2.47)$ & 442 \\
\hline & Sabadell & $0.45(-0.02,0.92)$ & 475 & $-1.39(-2.95,0.18)$ & 469 \\
\hline & Valencia & $-0.08(-0.34,0.18)$ & 585 & $-0.04(-0.53,0.46)$ & 585 \\
\hline \multirow[t]{4}{*}{ 4-5 years } & Asturias & $-0.16(-0.65,0.32)$ & 308 & $-0.42(-2.05,1.21)$ & 297 \\
\hline & Gipuzkoa & $0.27(-0.25,0.79)$ & 313 & $-1.53(-3.47,0.42)$ & 305 \\
\hline & Sabadell & $0.48(-0.08,1.03)$ & 395 & $-0.22(-2.14,1.69)$ & 390 \\
\hline & Valencia & $-0.12(-0.44,0.19)$ & 437 & $-0.03(-0.65,0.58)$ & 437 \\
\hline
\end{tabular}

${ }^{a}$ Additive change in the mean of the outcome when doubling the exposure, from a linear regression adjusted for area, age at examination, sex, psychologist, quality of the test, parity and maternal age, social class, born in Europe, alcohol and smoking during pregnancy, height, pre-pregnancy body mass index and weight gain during pregnancy.

${ }^{b}$ All route uptake is the total residential THM uptake through ingestion, showering and bathing. 
Supplemental Material, Table S5. Estimated change ${ }^{a}$ in neuropsychologial scales from a linear regression for doubling total trihalomethane exposure in average over pregnancy, by maternal social class.

\begin{tabular}{|c|c|c|c|c|c|c|}
\hline \multirow[t]{2}{*}{ Outcome } & \multicolumn{3}{|c|}{ Ingestion THM uptake ( $\mu \mathrm{g} /$ day) } & \multicolumn{3}{|c|}{ All route THM uptake $(\mu \mathrm{g} / \mathrm{day})^{b}$} \\
\hline & Effect $^{\mathrm{a}}(95 \% \mathrm{Cl})$ & $\mathrm{N}$ & $\begin{array}{l}\text { Inter. } \\
\text { p-val. }\end{array}$ & Effect $^{a}(95 \% \mathrm{Cl})$ & $\mathrm{N}$ & $\begin{array}{l}\text { Inter. } \\
\text { p-val. }\end{array}$ \\
\hline \multicolumn{7}{|c|}{ Mental/cognitive score, 1 year } \\
\hline Social class & & & 0.53 & & & 0.80 \\
\hline I, II, III & $-0.28(-0.58,0.02)$ & 906 & & $-0.20(-0.92,0.52)$ & 887 & \\
\hline $\mathrm{IV}, \mathrm{V}$ & $0.10(-0.17,0.37)$ & 949 & & $0.03(-0.58,0.65)$ & 936 & \\
\hline \multicolumn{7}{|l|}{ Mental score, $4-5$ years } \\
\hline Social class & & & 0.83 & & & 0.97 \\
\hline I, II, III & $0.14(-0.15,0.43)$ & 752 & & $-0.34(-1.05,0.36)$ & 737 & \\
\hline $\mathrm{IV}, \mathrm{V}$ & $0.20(-0.09,0.50)$ & 701 & & $-0.71(-1.39,-0.02)$ & 692 & \\
\hline \multicolumn{7}{|l|}{ Motor score, 1 year } \\
\hline Social class & & & 0.83 & & & 0.40 \\
\hline I, II, III & $-0.12(-0.41,0.17)$ & 906 & & $0.05(-0.65,0.74)$ & 887 & \\
\hline $\mathrm{IV}, \mathrm{V}$ & $-0.02(-0.27,0.23)$ & 949 & & $-0.09(-0.65,0.48)$ & 936 & \\
\hline \multicolumn{7}{|l|}{ Motor score, 4-5 years } \\
\hline Social class & & & $<0.01$ & & & 0.83 \\
\hline I, II, III & $0.39(0.10,0.68)$ & 752 & & $0.00(-0.72,0.72)$ & 737 & \\
\hline $\mathrm{IV}, \mathrm{V}$ & $-0.22(-0.53,0.09)$ & 701 & & $-0.30(-1.02,0.43)$ & 692 & \\
\hline
\end{tabular}

${ }^{a}$ Additive change in the mean of the outcome when doubling the exposure, from a linear regression adjusted for area, age at examination, sex, psychologist, quality of the test, parity and maternal age, social class, born in Europe, alcohol and smoking during pregnancy, height, pre-pregnancy body mass index and weight gain during pregnancy.

${ }^{b}$ All route uptake is the total residential THM uptake through ingestion, showering and bathing. 
Ingestion THM uptake

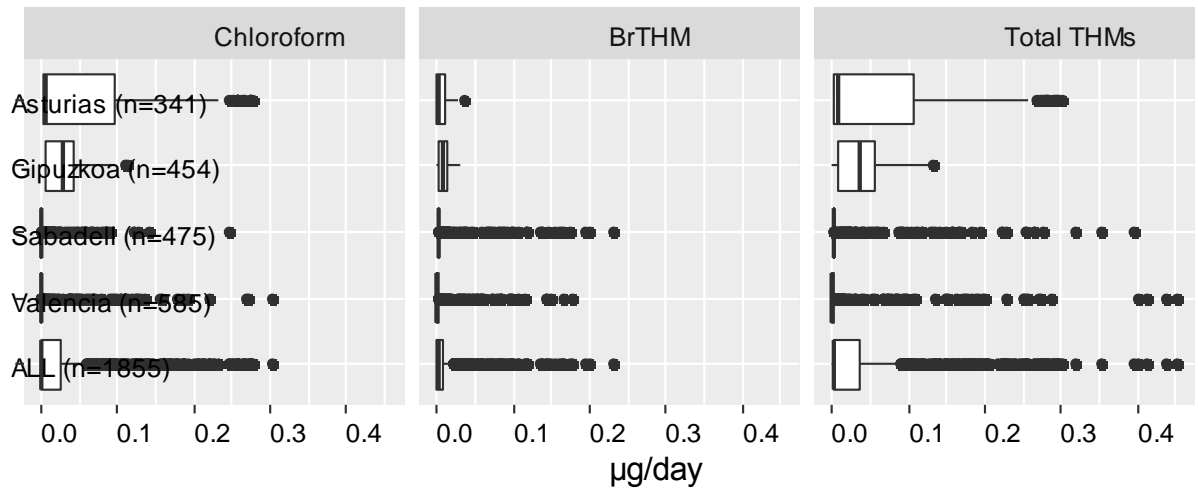

All route THM uptake

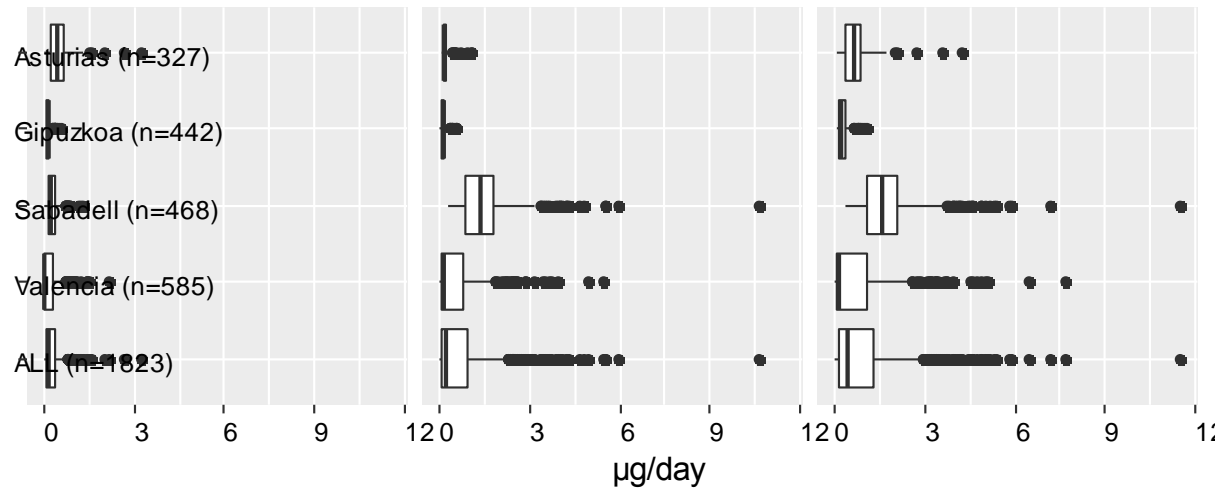

THM levels
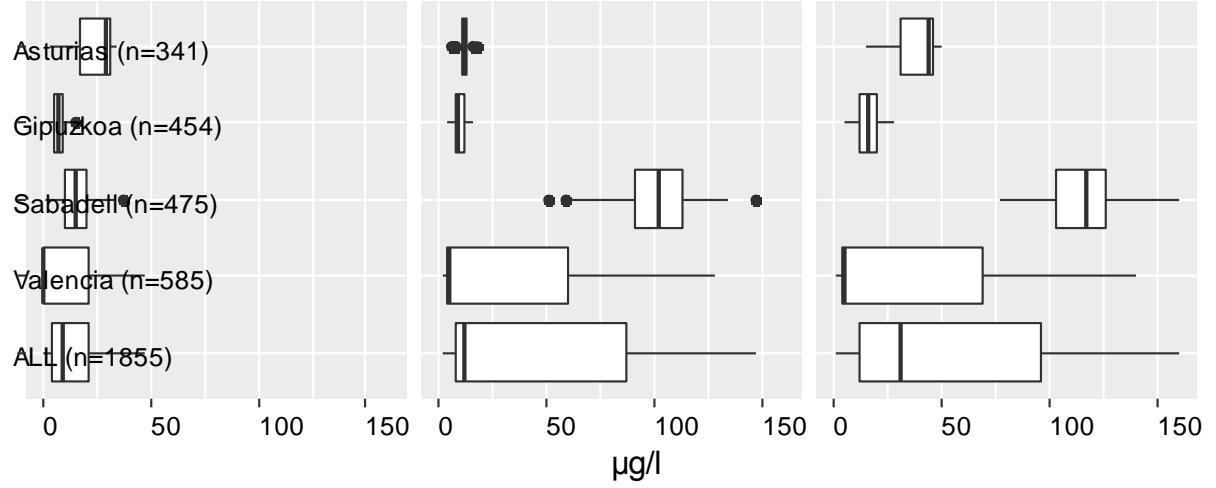

Haloacetic Acids

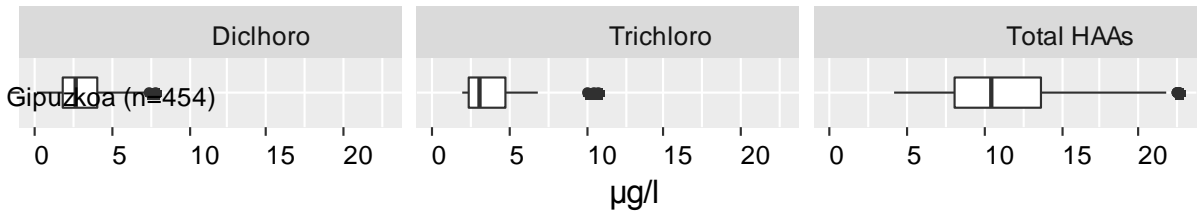




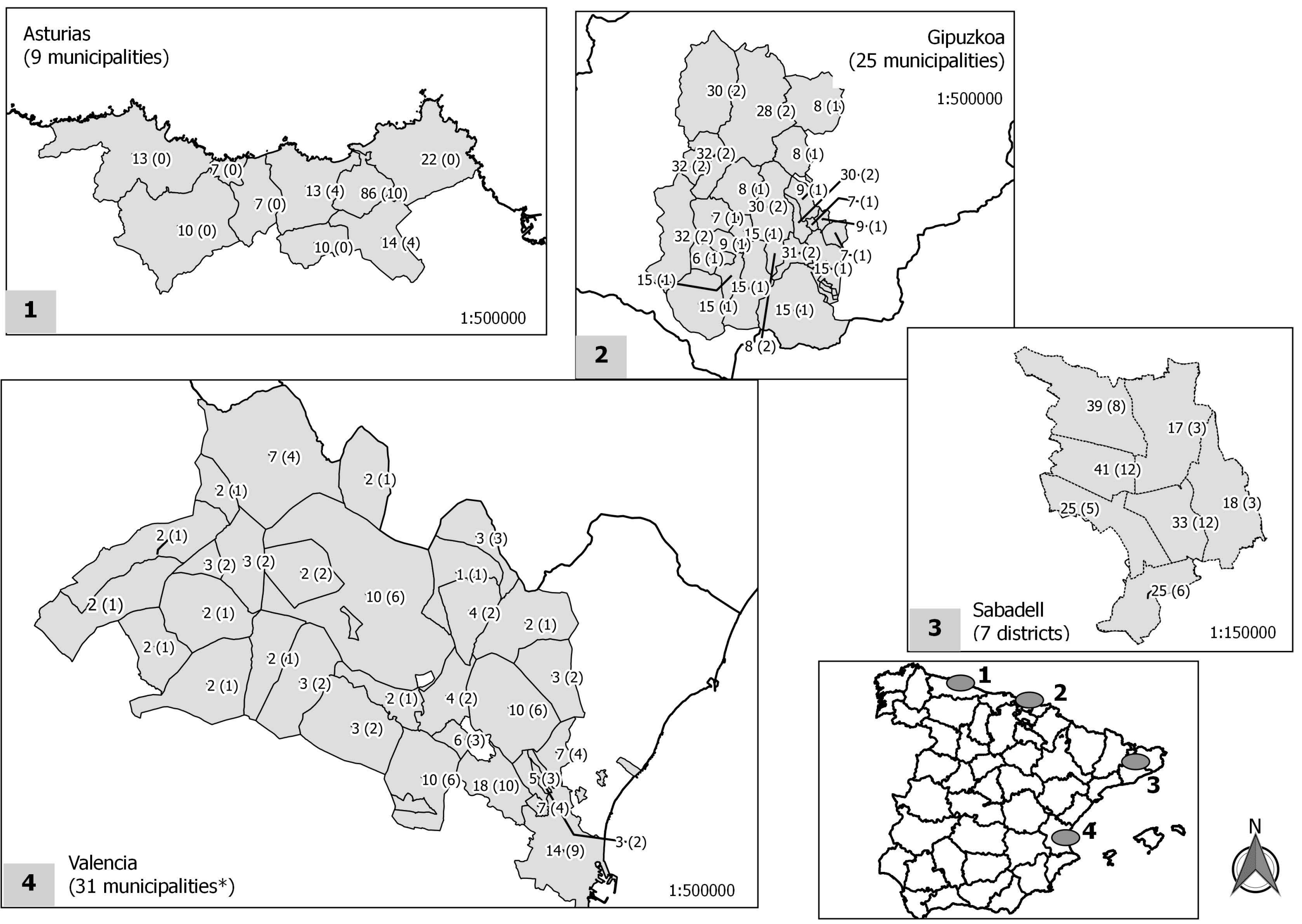


Mental/Cognitive

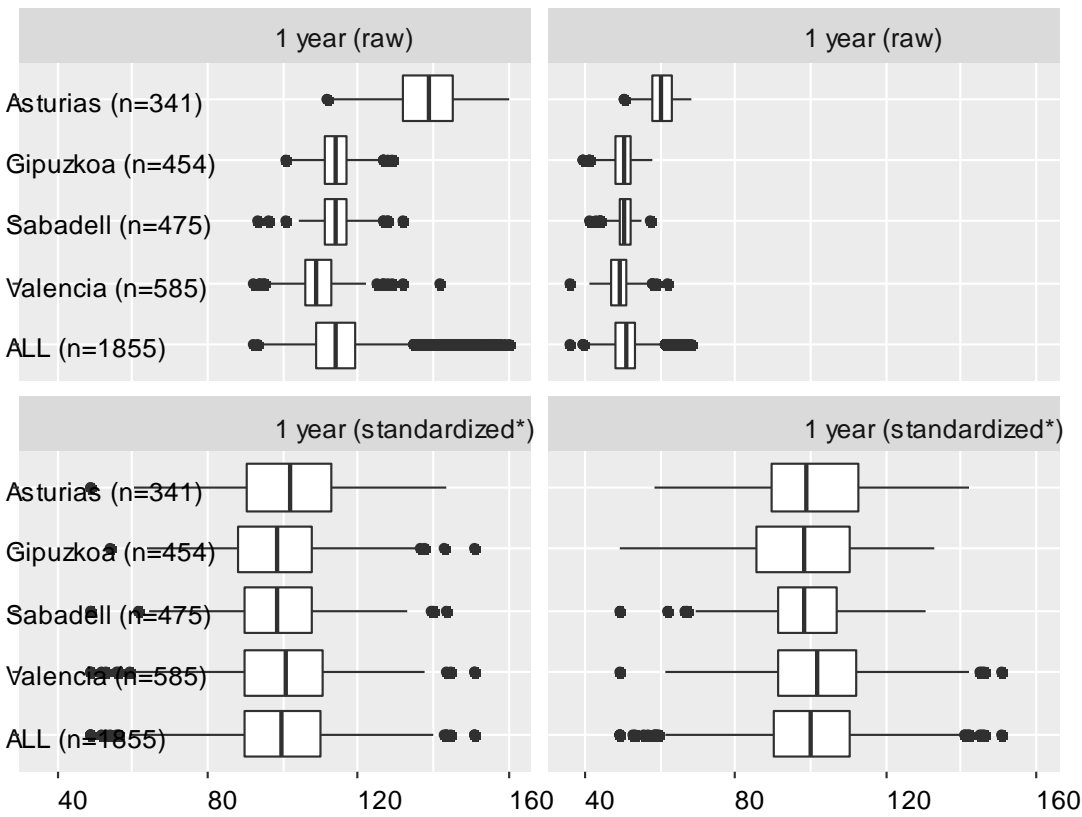

4-5 years (raw)

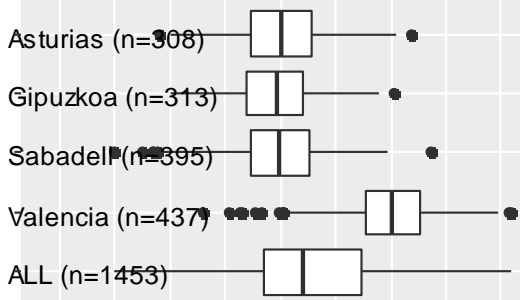

4-5 years (standardiz
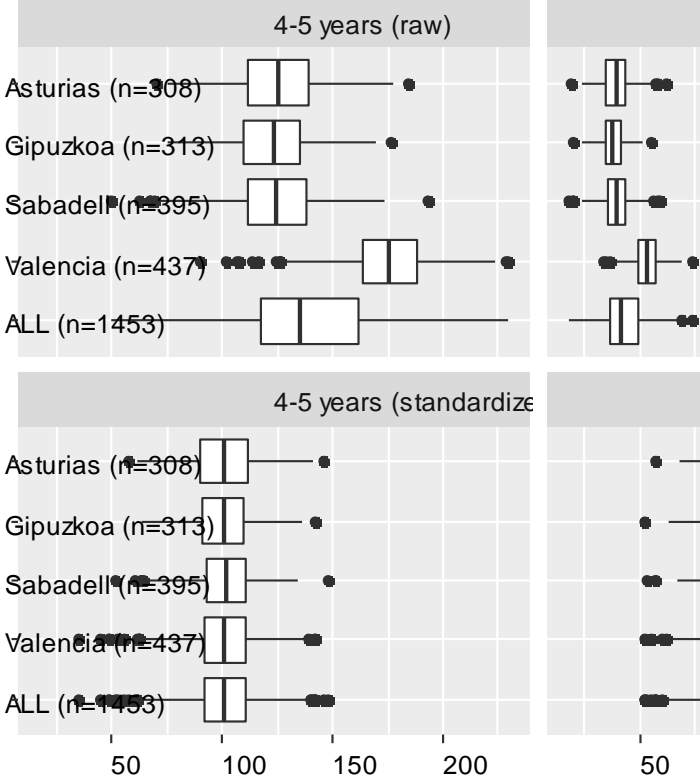

4-5 years (raw)

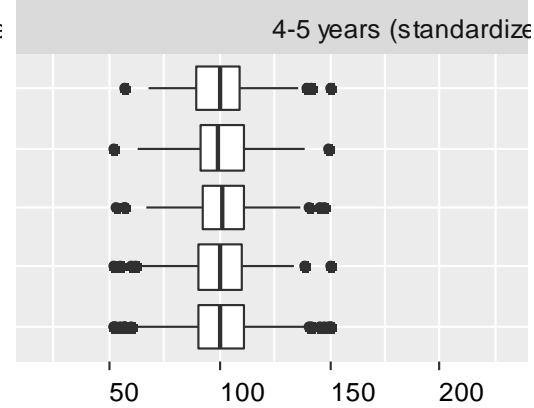

* Age-adjusted and centered by cohort to a mean of 100 and standard deviation of 15 points. ** Centered by cohort to a mean of 100 and standard deviation of 15 points. 


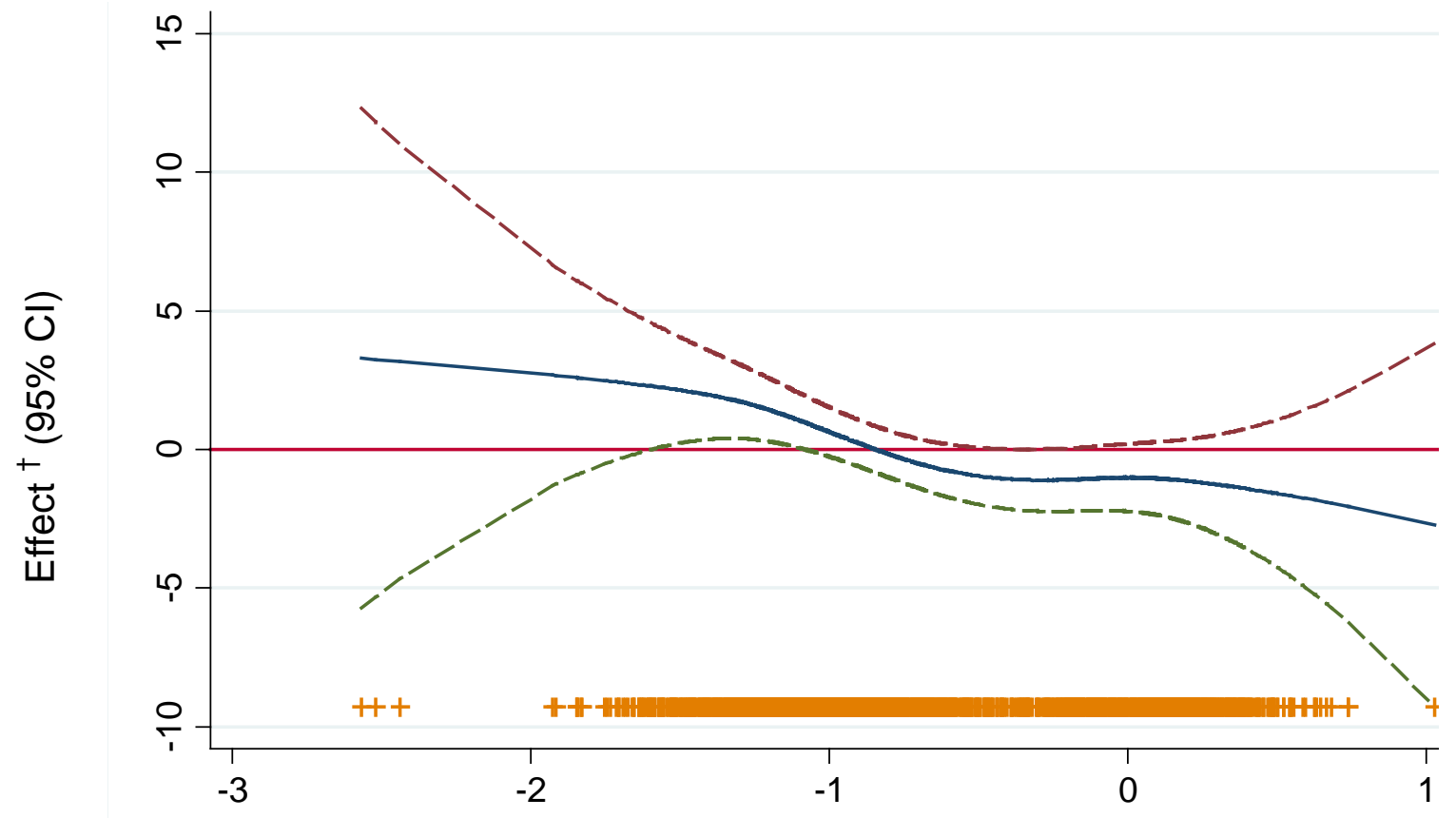

Log brominated THM all route uptake 